\title{
Preliminary Analysis of the General Performance and Mechanical Behavior of Irradiated FeCrAl Base Alloys and Weldments
}

Approved for public release.

Distribution is unlimited.
Maxim N. Gussev

Kevin G. Field

Samuel A. Briggs

Yukinori Yamamoto

September $30^{\text {th }}, 2016$ 


\section{DOCUMENT AVAILABILITY}

Reports produced after January 1, 1996, are generally available free via US Department of Energy (DOE) SciTech Connect.

Website http://www.osti.gov/scitech/

Reports produced before January 1, 1996, may be purchased by members of the public from the following source:

National Technical Information Service

5285 Port Royal Road

Springfield, VA 22161

Telephone 703-605-6000 (1-800-553-6847)

TDD 703-487-4639

Fax 703-605-6900

E-mail info@ntis.gov

Website http://www.ntis.gov/help/ordermethods.aspx

Reports are available to DOE employees, DOE contractors, Energy Technology Data Exchange representatives, and International Nuclear Information System representatives from the following source:

Office of Scientific and Technical Information

PO Box 62

Oak Ridge, TN 37831

Telephone 865-576-8401

Fax 865-576-5728

E-mail reports@osti.gov

Website http://www.osti.gov/contact.html

This report was prepared as an account of work sponsored by an agency of the United States Government. Neither the United States Government nor any agency thereof, nor any of their employees, makes any warranty, express or implied, or assumes any legal liability or responsibility for the accuracy, completeness, or usefulness of any information, apparatus, product, or process disclosed, or represents that its use would not infringe privately owned rights. Reference herein to any specific commercial product, process, or service by trade name, trademark, manufacturer, or otherwise, does not necessarily constitute or imply its endorsement, recommendation, or favoring by the United States Government or any agency thereof. The views and opinions of authors expressed herein do not necessarily state or reflect those of the United States Government or any agency thereof. 
Nuclear Energy Enabling Technologies (NEET): Reactor Materials

Preliminary Analysis of the General Performance and Mechanical Behavior of Irradiated FeCrAl Base Alloys and Weldments

\author{
Maxim N. Gussev \\ Kevin G. Field \\ Samuel A. Briggs \\ Yukinori Yamamoto
}

Date Published: September $30^{\text {th }}, 2016$

\title{
Prepared by
}

OAK RIDGE NATIONAL LABORATORY

Oak Ridge, TN 37831-6283

managed by

UT-BATTELLE, LLC

for the

US DEPARTMENT OF ENERGY

under contract DE-AC05-00OR22725 



\section{CONTENTS}

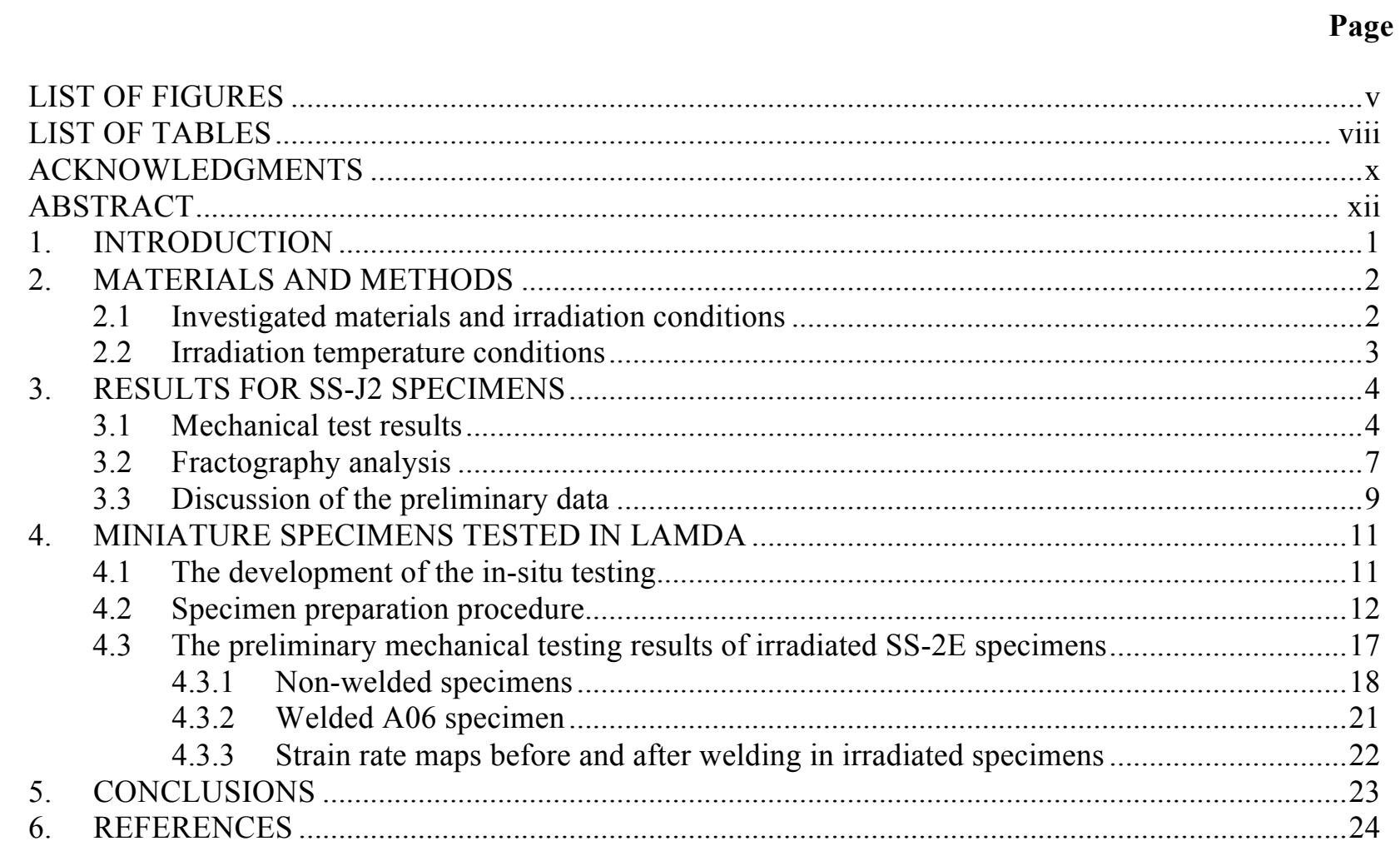





\section{LIST OF FIGURES}

Figure 1. Optical micrograph showing the two sub-sized tensile specimen geometries irradiated in the central flux trap of the HFIR.

Figure 3. Nominal irradiation temperatures determined from in-capsule passive SiC thermometry for FCAT01-03 irradiation capsules.

Figure 3. Plots showing engineering stress-strain curves before and after neutron irradiation to 1.8 1.9 dpa: (a) non-welded parent material $\left(\mathrm{T}_{\text {test }}=24^{\circ} \mathrm{C}\right)$ and (b) weldments $\left(\mathrm{T}_{\text {test }}=24^{\circ} \mathrm{C}\right)$. $\mathrm{C} 36 \mathrm{M}$ weldments were not studied as they were not included within the irradiation campaign.

Figure 5. Optical micrographs showing necking behavior in the irradiated parent material $(\mathrm{a}, \mathrm{c}, \mathrm{e})$ and irradiated weldments (b,d,f) in C35M: (a-b) $1.9 \mathrm{dpa}, 195^{\circ} \mathrm{C}$, (c-d) $1.8 \mathrm{dpa}, 363^{\circ} \mathrm{C}$, (e-f) $1.9 \mathrm{dpa}, 566^{\circ} \mathrm{C}$.

Figure 6. SEM micrographs (low and high magnification) showing the fracture surfaces after tensile testing in the irradiated condition for parent materials of C35M: (a-b) $1.9 \mathrm{dpa}, 195^{\circ} \mathrm{C}$, (c-d) $1.8 \mathrm{dpa}, 363^{\circ} \mathrm{C}$, (e-f) $1.9 \mathrm{dpa}, 566^{\circ} \mathrm{C}$.

Figure 7. SEM micrographs (low and high magnification) showing the fracture surfaces after tensile testing in the irradiated condition for weldments of C35M: (a-b) $1.9 \mathrm{dpa}, 195^{\circ} \mathrm{C}$, (c-d) $1.8 \mathrm{dpa}, 363^{\circ} \mathrm{C}$, (e-f) $1.9 \mathrm{dpa}, 566^{\circ} \mathrm{C}$.

Figure 8. General view of the MZ.Sb small tensile stage for the VERSA 3-D SEM (left). Tensile stage with a high-temperature heater installed in the SEM microscope chamber (image provided by the vendor, Kammrath and Weiss Technologies, Inc.).

Figure 9. Representative EBSD data set (Inverse Pole Figure, IPF, Image Quality, IQ, Grain Reference Orientation Deviation, GROD, and Kernel Average Misorientation, KAM maps) for the specimen cross-section (weldment of C35M alloy). One may see the signs of pronounced cold work (orientation change in IPF maps and high local misorientation in the GROD and KAM maps) near the specimen surface (scan edge, top of image).

Figure 10. KAM profiles from two different locations as a function of depth (distance from the surface). KAM profiles averaging width: 20 data points.

Figure 11. Left: Strain-induced relief near the fracture location $(\sim 50 \mu \mathrm{m}$ from the fracture point). Right: cracks associated with inclusions; grain boundaries are also visible. $0^{\circ}$-tilt.................15

Figure 12. Strain-induced relief near the fracture location (maximum strain level). $70^{\circ}$-tilt.

Figure 13. EBSD data set for the specimen surface after deformation. The scan was taken near the fracture location with a scanning rate of $\sim 57$ points per second, i.e. usual rate. Top left, IPF; top right IQ; bottom left, GROD; bottom right, KAM.

Figure 14. Representative EBSD patterns recorded for the same specimen before (left) and after (right) plastic deformation. Using DIC data, local strain level was estimated as $\sim 0.2-0.3$ in true strain units (Hencky's strain).

Figure 14. Image demonstrating the DIC pattern density and quality.....

Figure 15. Several frames taken during the tensile test (non-welded F03 specimen) with color maps showing strain distribution (Green-Lagrange strain tensor). Insertion at the right shows raw tensile data (load, $\mathrm{N}$ vs experiment time).

Figure 16. Strain distribution along the gage for the F03 specimen. Insertion at the left shows the image of the specimen prior to testing. The inserted diagram at the right demonstrates the tensile diagram and the location of the DIC frames (\#60,\#70, etc.). The main plot shows von Mises strain (vM); Green-Lagrange tensor was employed. The results may be expressed using any strain metric (engineering strain or true strain); however, Green-Lagrange strain definition is the most common one for DIC. 
Figure 17. Strain distribution (von Mises strain, vM, developed from Green-Lagrange tensor) along the gage for the F06 specimen. The inserted diagram at the right demonstrates the tensile curve and the location of the DIC frames (\#60, \#100, etc.)...

Figure 18. Strain distribution (von Mises strain, Green-Lagrange tensor) along the gage for the A06 (welded) specimen (see insertion at the left). The diagram at the right demonstrates the tensile curve for this specimen and the location of the DIC frames (\#40, \#60, etc.).

Figure 19. Strain rate maps for F06 (non-welded) and A06 (welded) specimens. YS and Neck show the offset plastic yielding and necking, respectively.... 



\section{LIST OF TABLES}

Table 1. Candidate $\mathrm{FeCrAl}$ alloys processing routes and composition in weight percentage.....................2

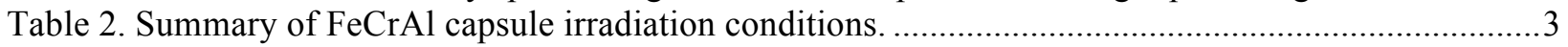

Table 3. Mechanical properties for SS-2E specimens vs. SS-J3 (dose $1.8-1.9$ dpa) ..............................18 



\section{ACKNOWLEDGMENTS}

This research was sponsored by the US Department of Energy, Office of Nuclear Energy, for the Nuclear Energy Enabling Technologies (NEET) program for the Reactor Materials effort. Neutron irradiation of at ORNL's HFIR user facility was sponsored by the Scientific User Facilities Division, Office of Basic Energy Sciences, DOE. This report was authored by UT-Battelle LLC under Contract No. DE-AC0500OR22725 with the US Department of Energy. 



\begin{abstract}
The iron-based, iron-chromium-aluminum $(\mathrm{FeCrAl})$ alloys are promising, robust materials for deployment in current and future nuclear power plants. This class of alloys demonstrates excellent performance in a range of environments and conditions, including high-temperature steam $\left(>1000^{\circ} \mathrm{C}\right)$. Furthermore, these alloys have the potential to have prolonged survival under loss-of-coolant accident (LOCA) conditions compared to the more traditional cladding materials that are either Zr-based alloys or austenitic steels. However, one of the issues associated with $\mathrm{FeCrAl}$ alloys is cracking during welding. The present project investigates the possibility of mitigating welding-induced cracking via alloying and precise structure control of the weldments; in the frame work of the project, several advanced alloys were developed and are being investigated prior to and after neutron irradiation to provide insight into the radiation tolerance and mechanical performance of the weldments.

The present report provides preliminary results on the post-irradiation characterization and mechanical tests performed during United States Fiscal Year (FY) 2016. Chapter 1 provides a general introduction, and Chapter 2 describes the alloy compositions, welding procedure, specimen geometry and manufacturing parameters. Also, a brief discussion of the irradiation at the High Flux Isotope Reactor (HFIR) is provided. Chapter 3 is devoted to the analysis of mechanical tests performed at the hot cell facility; tensile curves and mechanical properties are discussed in detail focusing on the irradiation temperature. Limited fractography results are also presented and analyzed. The discussion highlights the limitations of the testing within a hot cell. Chapter 4 underlines the advantages of in-situ testing and discusses the preliminary results obtained with newly developed miniature specimens. Specimens were moved to the Low Activation Materials Development and Analysis (LAMDA) laboratory and prepared for mechanical tests. Tensile tests were conducted at LAMDA using a modern digital image correlation approach allowing for strain distribution analysis. Plastic strain initiation and necking are discussed in detail; a concept of strain rate maps is also introduced and discussed. Follow-on SEM-EBSD and FIBTEM analysis is planned.
\end{abstract}





\section{INTRODUCTION}

The iron-based, iron-chromium-aluminum ( $\mathrm{FeCrAl})$ alloy class shows promise as a robust material for deployment in current and future nuclear power plants [1,2]. Studies on modern FeCrAl alloys have demonstrated their excellent environmental compatibility, including resistance to aqueous corrosion, heavy metal compatibility, and oxidation resistance in high-temperature steam [3,4], as well as radiation responses on par with those of similar ferritic/martensitic steels [5-7]. Such properties have lead the $\mathrm{FeCrAl}$ alloy class to be conceptualized for use in a range of nuclear reactor materials deployments including as cladding materials with enhanced accident tolerance for light water reactors (LWRs), in the dual-coolant lead-lithium (DCLL) blanket concept for fusion reactor technologies, and as structural components for advanced fast reactor designs.

Given this, several studies have reported the sensitivity of FeCrAl alloys to cracking during welding [811]. Welding would be required in several of these nuclear applications to form the final component. Dupont et al. [8] and Regina et al. [9] have linked the welding-induced cracking to be due to the free hydrogen interacting with the microstructure in FeCrAl alloys. For the study of Dupont et al., hydrogen impurities were introduced into the cover gas which induced significant cracking in a FeCrAl weld overlay, while welds performed without the impurities showed no cracking. Regina et al. showed the susceptibility of an alloy to cracking during welding where water was present; the effect was determined to be composition dependent where alloys with high $\mathrm{Cr}$ and/or Al contents more readily reacted with water to form free hydrogen leading to similar cracking shown by Dupont et al. The possibility of this cracking mechanism in selected nuclear-relevant $\mathrm{FeCrAl}$ alloys using laser-based welding techniques has been previously investigated [12]. That study showed that weldments performed in the controlled atmosphere of laser based welding configurations did not display this susceptibility.

Given these details, no studies have investigated the impact of radiation on the performance of welds in FeCrAl alloys. Of primary concern is the modification of the highly controlled base microstructures during welding. Fusion-based welding requires high heat input that leads to melting in the fusion zone and significant temperature increases in regions surrounding the fusion zone leading to the wellestablished heat-affected zone (HAZ) in the weldments. These effects lead to a loss of the controlled microstructure in the fusion zone and HAZ. These important microstructural aspects, such as grain size, dislocation networks, and precipitate dispersions that can be lost or modified as the result of welding serve as primary defect sinks under irradiation. Modification in the defect sink density could lead to decreases in the radiation tolerance within these areas. Preliminary results have already shown that nonwelded $\mathrm{FeCrAl}$ alloys can exhibit radiation-induced hardening and embrittlement leading to degradation in material properties [5]. Clearly, detailed investigations into the radiation performance of $\mathrm{FeCrAl}$ weldments are needed before deployment of the $\mathrm{FeCrAl}$ alloy class in current or future nuclear power plants.

To date, no known studies have been performed evaluating the performance of irradiated $\mathrm{FeCrAl}$ weldments. To address this knowledge gap, a series of advanced, engineering grade $\mathrm{FeCrAl}$ alloys have been conceptualized, fabricated, welded and then irradiated in the High Flux Isotope Reactor (HFIR). This study reports on the initial post-irradiation examination efforts to evaluate the performance of both the base alloys and weldments exposed to neutron radiation environment at damage doses of 1.8-1.9 dpa at temperatures of $200^{\circ} \mathrm{C}, 330^{\circ} \mathrm{C}$, and $550^{\circ} \mathrm{C}$. Tensile tests of sub-sized and miniaturized tensile specimens and post-test fractography were used to determine the mechanical performance and properties of base material and weldments of five different $\mathrm{FeCrAl}$ alloys. The results and analysis within this study represent the on-going activity to develop highly weldable $\mathrm{FeCrAl}$ alloys with enhanced radiation tolerance. 


\section{MATERIALS AND METHODS}

\subsection{Investigated materials and irradiation conditions}

Materials for irradiation and subsequent post irradiation examination (PIE) included five advanced, engineering-grade $\mathrm{FeCrAl}$ base alloys and weldments with varying $\mathrm{Cr}$, $\mathrm{Al}$, and minor alloying additions. Alloys and their weldments can be grouped into three sub-classes including FeCrAl alloys with high-Al additions (6-7 wt\% Al, designated as C36M and C37M), a FeCrAl alloy with Laves precipitate dispersions (designated as $\mathrm{C} 35 \mathrm{MN}$ ), and a $\mathrm{FeCrAl}$ alloy with $\mathrm{TiC}$ precipitate dispersions (designated as C35M10TC). The alloys are all derivatives of the primary alloy, C35M, which is a FeCrAl alloy with a nominal composition of Fe-13Cr-5Al-2Mo-0.2Si-0.05Y (in wt. $\%$ ) and a ferritic matrix with grain sizes on the order of $10 \mu \mathrm{m}$. Alloy production routes and compositions determined using inductively coupled plasma optical emission spectroscopy (ICP-OES) are provided in Table 1. Base alloys all showed ferritic grain structures; microstructures can be found in [13] and references within.

Table 1. Candidate FeCrAl alloys processing routes and composition in weight percentage.

\begin{tabular}{lccccccccccccc}
\hline \multicolumn{1}{c}{ Alloy } & Fe & Cr & Al & $\mathbf{Y}$ & $\mathbf{M o}$ & $\mathbf{S i}$ & $\mathbf{N b}$ & $\mathbf{C}$ & $\mathbf{S}$ & $\mathbf{O}$ & $\mathbf{N}$ & $\mathbf{P}$ & $\mathbf{T i}$ \\
\hline C35M $^{1}$ & 79.43 & 13.06 & 5.31 & 0.053 & 2 & 0.13 & $<0.01$ & 0.001 & $<0.0003$ & 0.0012 & 0.0003 & 0.007 & $<0.01$ \\
C36M $^{\mathbf{1}}$ & 78.8 & 12.98 & 6 & 0.04 & 1.98 & 0.18 & $<0.01$ & 0.003 & $<0.0003$ & 0.0016 & 0.0002 & $<0.002$ & 0.01 \\
C37M $^{\mathbf{1}}$ & 77.49 & 13.01 & 7.22 & 0.081 & 1.99 & 0.19 & $<0.01$ & 0.001 & $<0.0003$ & 0.0026 & 0.0002 & 0.004 & $<0.01$ \\
C35MN $^{1}$ & 78.7 & 13 & 5.11 & 0.044 & 1.99 & 0.18 & 0.96 & 0.005 & 0.0003 & 0.0014 & 0.0002 & $<0.002$ & - \\
C35M10TC $^{2}$ & 78.82 & 12.95 & 5.14 & 0.01 & 1.96 & 0.2 & $<0.01$ & 0.18 & $<0.0003$ & 0.0012 & 0.0007 & $<0.002$ & 0.71 \\
\hline
\end{tabular}

Note: All other elements (Zr, B, Hf, V, W, Ce, Co, Cu, La, Mn, Ni) measured at or below $<0.01$

${ }^{1}$ Vacuum induction melt (VIM) ingot; ${ }^{2}$ Arc-melt and drop cast ingot.

Weldments were produced using a pulsed laser-welding machine. All welds were performed at room temperature and specimens were fixed prior to application of the laser. Welds were autogenous, bead-onplate welding. Full penetration welds were performed using a $7 \mathrm{~ms}$ pulse length, 7 pulses/s and a 2.12 $\mathrm{mm} / \mathrm{s}$ welding speed. Lamp energy was maintained near 100 Watts for the duration of the welding. Due to the slightly thicker feed-stock of the C35MN alloy, elevated parameters were needed for this alloy. All welding was performed in an inert argon cover gas. All welds were linear and conducted parallel to the traverse direction. Welding maintained the ferritic phase of the base alloy but lead to columnar grains emanating from the fusion line with grain sizes on the order of $25-75 \mu \mathrm{m}$.

Tensile specimens used in this study included dog-bone, sheet type SS-J2 specimens (thickness, $0.5 \mathrm{~mm}$ ) and miniaturized dog-bone, sheet type SS-2E specimens (thickness, $0.4 \mathrm{~mm}$ ) as shown in Figure 1 . The SS-J2 specimens were designated for hot cell testing to provide base-line mechanical properties. The SS$\mathrm{J} 2$ specimen geometry has been widely used as an irradiated specimen geometry for ferritic/martensitic steels as well as was the geometry of choice in prior irradiated FeCrAl studies. Thus, the SS-J2 geometry also provides cross-comparisons with results within the open literature. Additionally, SEM-based fractography analysis can be readily conducted on this specimen geometry. The SS-2E geometry was designed earlier [13] to allow for out-of-hot cell testing (instrumented mechanical testing, analysis of strain-induced structure evolution via FIB-TEM, etc.).

All machining was provided by a single vendor with the primary cuts being completed by electric discharge machining (EDM). For weldments, the fusion zone was aligned to the center of the gage region of both specimen geometries. At least two specimens per base alloy and weldment were irradiated per irradiation condition. Neutron irradiations were completed in the central flux trap of the High Flux Isotope Reactor (HFIR) at Oak Ridge National Laboratory (ORNL) at nominal doses of 1.8-1.9 dpa. 
Table 2Error! Reference source not found. provides details for each irradiation capsule.

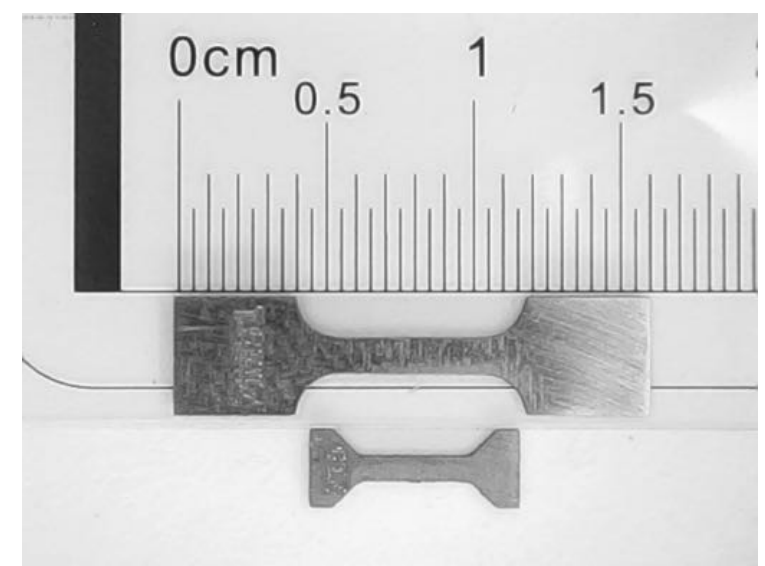

Figure 1. Optical micrograph showing the two sub-sized tensile specimen geometries irradiated in the central flux trap of the HFIR.

Target irradiation temperatures included $200^{\circ} \mathrm{C}, 330^{\circ} \mathrm{C}$, and $550^{\circ} \mathrm{C}$. Nominal irradiation temperatures were determined using passive SiC thermometry samples that were co-irradiated with the SS-J2 and SS$2 \mathrm{E}$ specimens. Two $\mathrm{SiC}$ specimens were tested per module (three modules are assembled vertically in a single capsule), one from the "East Lobe" and one from the "West Lobe" to provide insight into the axial and radial temperature gradients under irradiation [14]. No SiC specimens survived hot cell handling in the bottom module of the $200^{\circ} \mathrm{C}$ capsule in the West Lobe and hence no analysis from this region is reported. Dilatometric analysis using a Netzsch $402 \mathrm{CD}$ dilatometer was conducted up to a maximum temperature of $600^{\circ} \mathrm{C}$ for the $200^{\circ} \mathrm{C}$ and $330^{\circ} \mathrm{C}$ irradiation capsules and $900^{\circ} \mathrm{C}$ for the $550^{\circ} \mathrm{C}$ irradiation capsules. A constant ramp rate of $1{ }^{\circ} \mathrm{C} / \mathrm{min}$ and a cooling rate of $2.5^{\circ} \mathrm{C} / \mathrm{min}$ by used. Outputted data from the dilatometric technique was analyzed using the methodology outlined by Campbell et al. [15].

Table 2. Summary of FeCrAl capsule irradiation conditions.

\begin{tabular}{|c|c|c|c|c|c|c|}
\hline Capsule ID & $\begin{array}{c}\text { Exposure } \\
\text { Time } \\
\text { (hrs) }\end{array}$ & 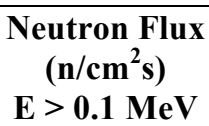 & $\begin{array}{c}\text { Neutron Fluence } \\
\left(\mathbf{n} / \mathrm{cm}^{2}\right) \\
\mathrm{E}>0.1 \mathrm{MeV}\end{array}$ & $\begin{array}{c}\text { Dose Rate } \\
\text { (dpa/s) }\end{array}$ & $\begin{array}{l}\text { Dose } \\
\text { (dpa) }\end{array}$ & $\begin{array}{c}\text { Irradiation } \\
\text { Temperature } \\
\left({ }^{\circ} \mathrm{C}\right)\end{array}$ \\
\hline FCAT-01 & 548 & $1.10 \times 10^{15}$ & $2.17 \times 10^{21}$ & $9.8 \times 10^{-7}$ & 1.9 & 200 \\
\hline FCAT-02 & 548 & $1.04 \times 10^{15}$ & $2.05 \times 10^{21}$ & $9.3 \times 10^{-7}$ & 1.8 & 330 \\
\hline FCAT-03 & 548 & $1.10 \times 10^{15}$ & $2.17 \times 10^{21}$ & $9.8 \times 10^{-7}$ & 1.9 & 550 \\
\hline
\end{tabular}

\subsection{Irradiation temperature conditions}

Figure 2 summarizes the resulting analysis of the passive $\mathrm{SiC}$ thermometry. SiC thermometry is anticipated to have higher reported temperatures than nominal specimen average irradiated specimens due to the thermometry being orientated radially closer to the assembly center. Target average SiC modeled temperatures based on an ANSYS finite element analysis (FEA) model are highlighted on the y-axis of Figure 2 while the average temperature from all investigated $\mathrm{SiC}$ per capsule is highlighted as the light gray line. The $330^{\circ} \mathrm{C}$ and $550^{\circ} \mathrm{C}$ irradiations showed the closest match between the expected and determined value $\left(<15^{\circ} \mathrm{C}\right.$ variance $)$, while the $200^{\circ} \mathrm{C}$ irradiation had a larger variance $\left(-47.5^{\circ} \mathrm{C}\right)$, indicating the lowest temperature irradiation could be significantly lower than the design temperature of $200^{\circ} \mathrm{C}$. The low variance between the modeled and experimentally determined values for the $330^{\circ} \mathrm{C}$ and 
$550^{\circ} \mathrm{C}$ irradiation capsule suggests that specimen average values were within tolerances of the bulk specimen average values.

Figure 2 also shows that East Lobe specimens tended to run at higher temperatures than West Lobe specimens. East Lobes were placed adjacent to SS-2E specimen configurations while the West Lobe specimens were placed adjacent to the SS-J2 specimens. The temperatures shown in Figure 2 would suggest the more complex packing design with more mating surfaces of the SS-2E specimen configurations contributed to the observed increase in temperature in this region. Hence, small variations in radiation temperature could be possible between the SS-2E and SS-J2 specimens. Some axial variation within each irradiation capsule is also shown in Figure 2. This could be due to the capsules being offcentered from the centerline of the reactor core, but tracking of the capsule orientation within the reactor was not completed.

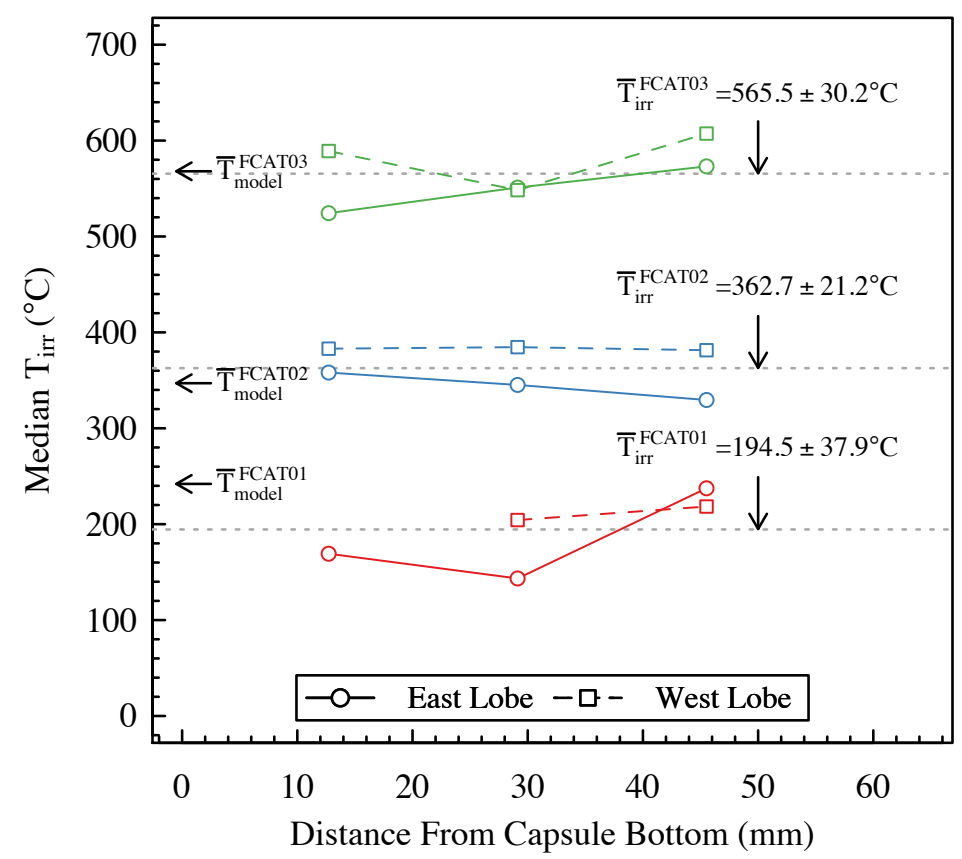

Figure 2. Nominal irradiation temperatures determined from in-capsule passive SiC thermometry for FCAT01-03 irradiation capsules.

\section{RESULTS FOR SS-J2 SPECIMENS}

\subsection{Mechanical test results}

Tensile tests for the SS-J2 specimens in the as-received and irradiated state were performed using an Instron universal test machine at room temperature. Shoulder loading using a crosshead speed of 0.0055 $\mathrm{mm} / \mathrm{s}$ was employed, resulting in a nominal strain rate of $\sim 10^{-3} \mathrm{~s}^{-1}$. For the SS-J2 specimens, no postirradiation surface preparation was completed prior to testing. Engineering stress-strain curves were calculated based on the digitally recorded load/crosshead displacement and measured cross-section of the gage region. All gage measurements were performed prior to irradiation and hence no correction was made for volumetric swelling in the specimens after neutron irradiation, although swelling was assumed negligible based on the reports of Little and Stow [7]. Tensile tests were performed in a protective hot cell preventing application of optical, non-contact strain measurements. Fracture tensile surfaces of the C35M 
alloy and its weldment in the SS-J2 configuration after tensile testing was imaged using a remotely operated JEOL JSM-6010LA scanning electron microscope (SEM). Investigations on the other alloys and their weldments will be completed at a future date. SEM imaging was completed with a $5 \mathrm{kV}$ beam operating at a $10 \mathrm{~mm}$ working distance.

Engineering stress-strain curves for the base alloys and weldments tested in the SS-J2 geometry are provided in Figure 3a and Figure 3b, respectively. Base alloys all performed in a similar manner, regardless of initial composition and/or microstructure. Irradiation at $200^{\circ} \mathrm{C}$ and $330^{\circ} \mathrm{C}$ to $1.8-1.9 \mathrm{dpa}$ showed increases in yield strength which is correlated to a loss of ductility and reduction of load carry capacity after yielding for all base alloys. Irradiation to $200^{\circ} \mathrm{C}$ showed a more severe response with significant increases in the yield strength and reduction of the ductility when compared to the $330^{\circ} \mathrm{C}$ irradiation. For the base alloys, irradiation to $550^{\circ} \mathrm{C}$ showed radiation-induced softening, with decreases in yield strength and increases in the total elongation.

The weldments showed drastically different tensile behavior compared to the base alloys. When irradiated to $550^{\circ} \mathrm{C}$, the weldments showed little change in overall tensile properties compared to the as-received state. At lower irradiation temperatures, the weldments tended to fail in the elastic regime with the failure stress decreasing with decreasing irradiation temperature in the $\mathrm{C} 37 \mathrm{M}$ alloy. The difference in the failure state of the specimens between the base alloy and the weldment can be seen in Figure 4. The C35M base alloy specimens shown in Figure 4 exhibited typical necking and some degree of reduction of area while the weldments typically showed little or no necking and reduction of area when irradiated to $200^{\circ} \mathrm{C}$ and $330^{\circ} \mathrm{C}$. Fracture of weldments were biased towards the gage center, Figure 4, indicating failure in the fusion zone or surrounding zones and not in the base alloy regions of the gage. 

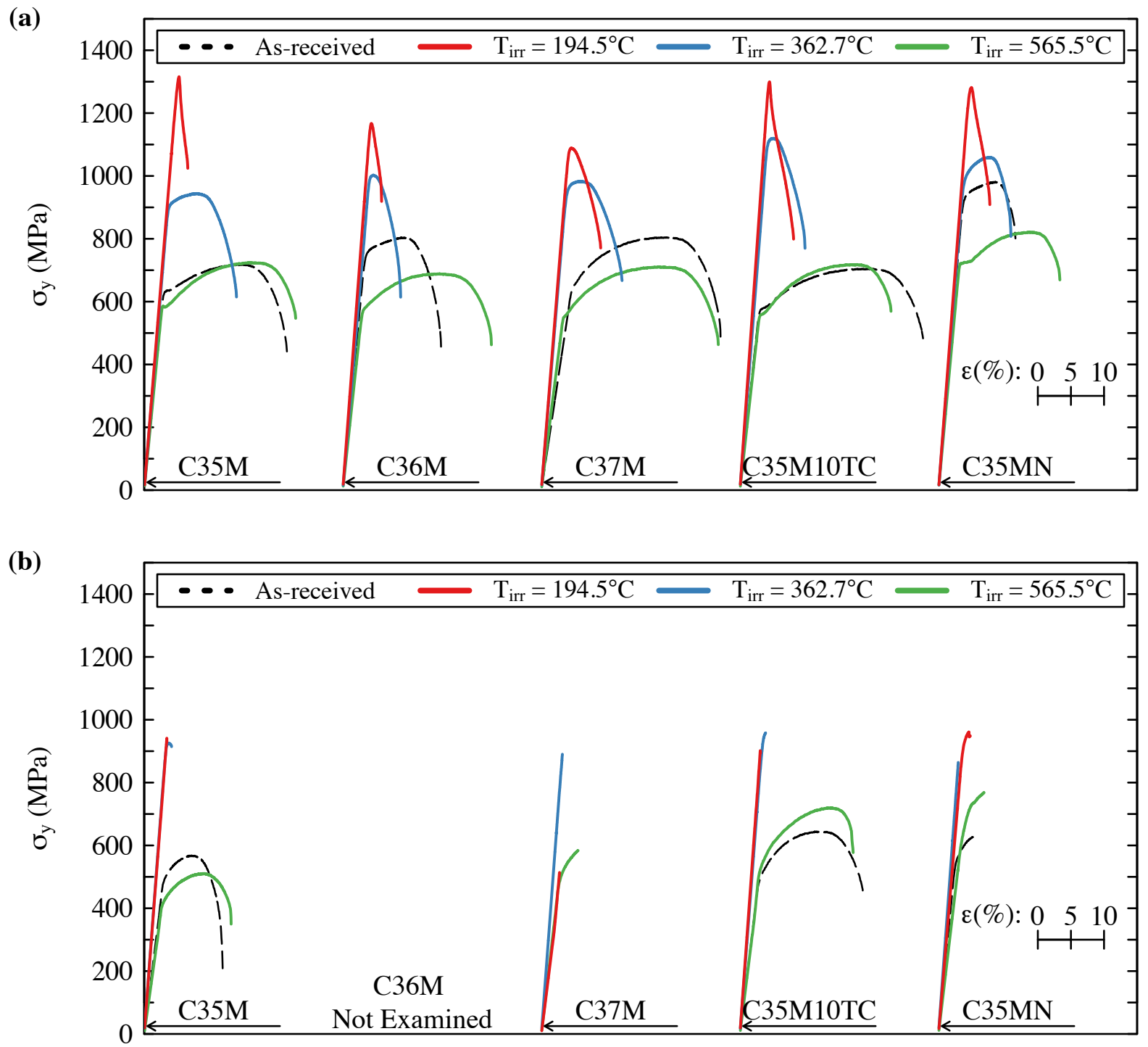

Figure 3. Plots showing engineering stress-strain curves before and after neutron irradiation to 1.8-1.9 dpa: (a) non-welded parent material $\left(T_{\text {test }}=24^{\circ} \mathrm{C}\right)$ and $(b)$ weldments $\left(T_{\text {test }}=24^{\circ} \mathrm{C}\right)$. C36M weldments were not studied as they were not included within the irradiation campaign. 
(a)

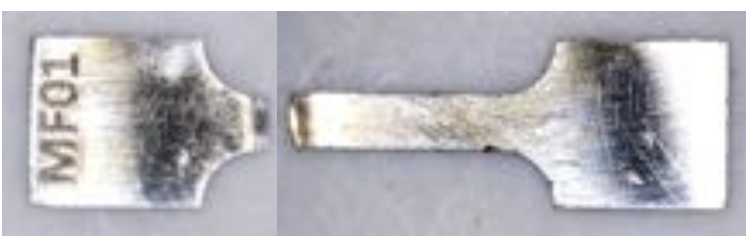

(c)

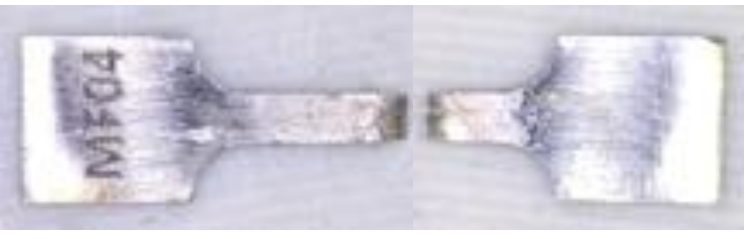

(e)

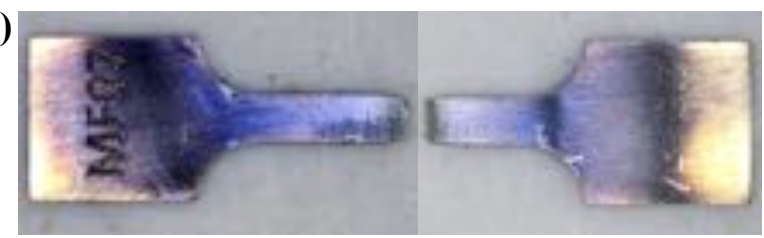

(b)

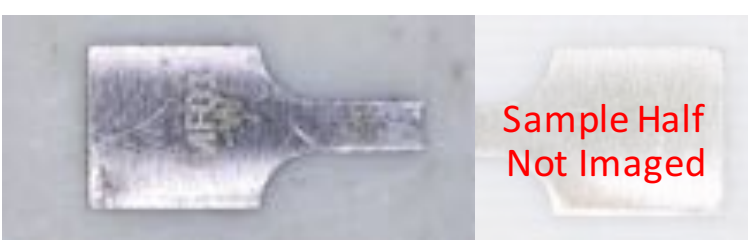

(d)

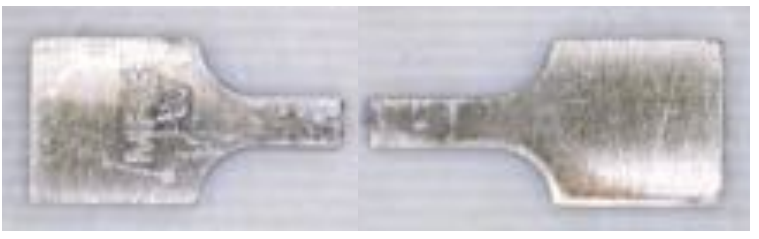

(f)

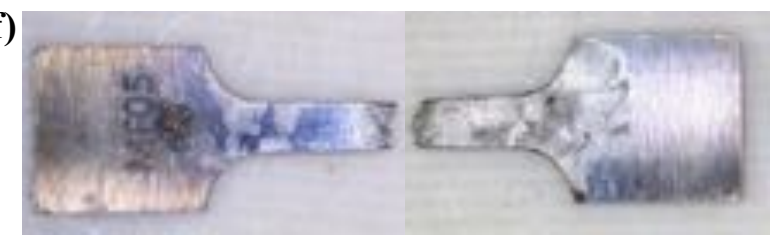

Figure 4. Optical micrographs showing necking behavior in the irradiated parent material (a,c,e) and irradiated weldments (b,d,f) in C35M: (a-b) $1.9 \mathrm{dpa}, 195^{\circ} \mathrm{C}$, (c-d) $1.8 \mathrm{dpa}, 363^{\circ} \mathrm{C}$, (e-f) $1.9 \mathrm{dpa}, 566^{\circ} \mathrm{C}$.

\subsection{Fractography analysis}

Figure 5 and Figure 6 show typical fracture surfaces from the SS-J2 specimens tested and imaged in Figure 4 for the C35M base alloy and weldments. The base alloy showed typical dimple ductile fracture after room temperature tensile testing regardless of irradiation temperature (Figure 5). Hard inclusions were observed to reside in the dimple regions in the specimen irradiated $200^{\circ} \mathrm{C}$, as shown in Figure $5 \mathrm{~b}$. Based on the optical micrographs and SEM-based fractography, it can be concluded that the base C35M alloy, and presumably all other alloys as they have similar tensile responses, failed in a ductile fracture mode and that the fractures were not highly localized due to the observed high degree of necking and reduction of area. The brittle fracture mode of the weldments when irradiated to either $200^{\circ} \mathrm{C}$ or $330^{\circ} \mathrm{C}$ is evidenced by faceted textures and river markings in the fractographs in Figure 6 . The C35M weldment irradiated to $550^{\circ} \mathrm{C}$ showed interesting fracture surfaces with indications of a mixed fracture mode where both transgranular cleavage and dimple-cone structures occurred. The mixed mode correlates with the observed tensile response in Figure 3b. 
(a)

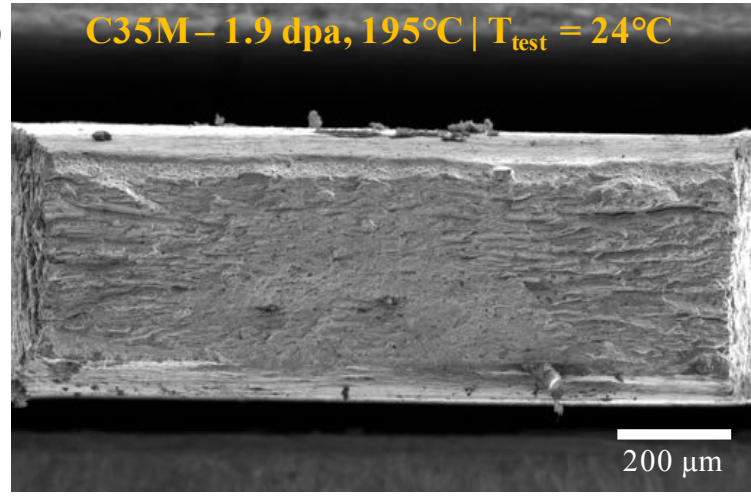

(c)

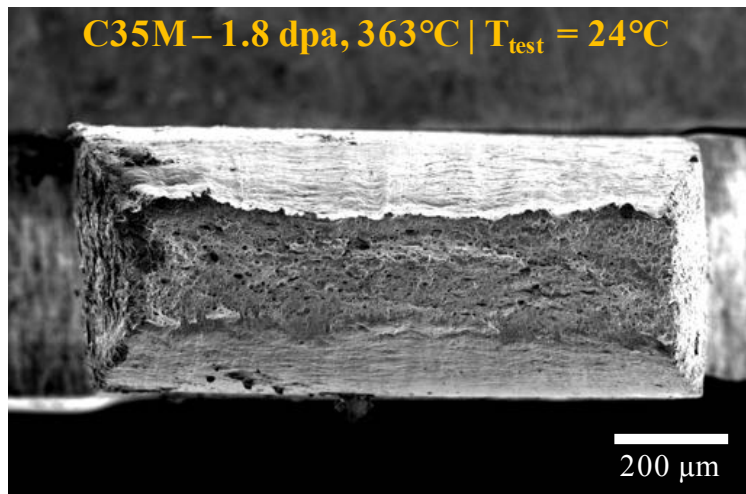

(e)

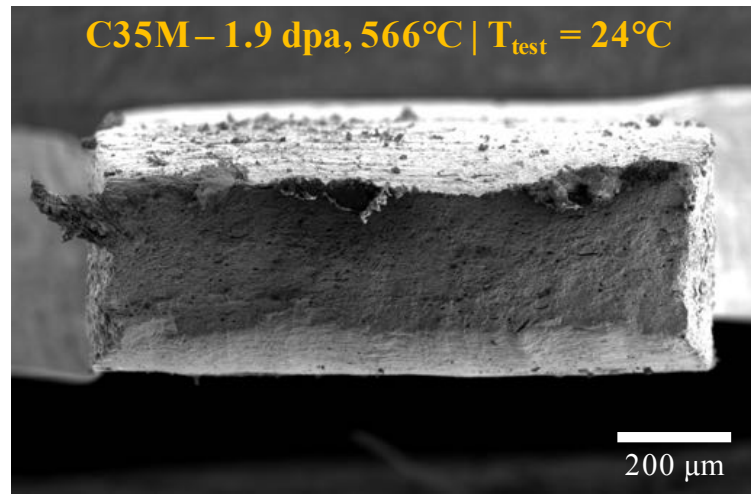

(b)

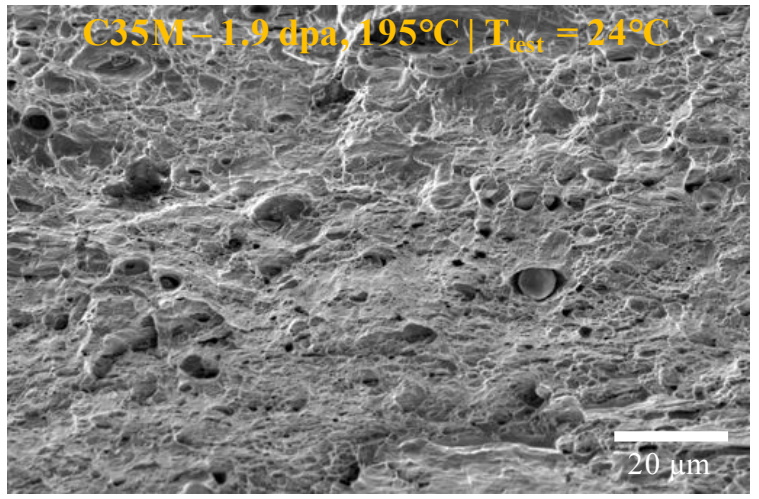

(d)

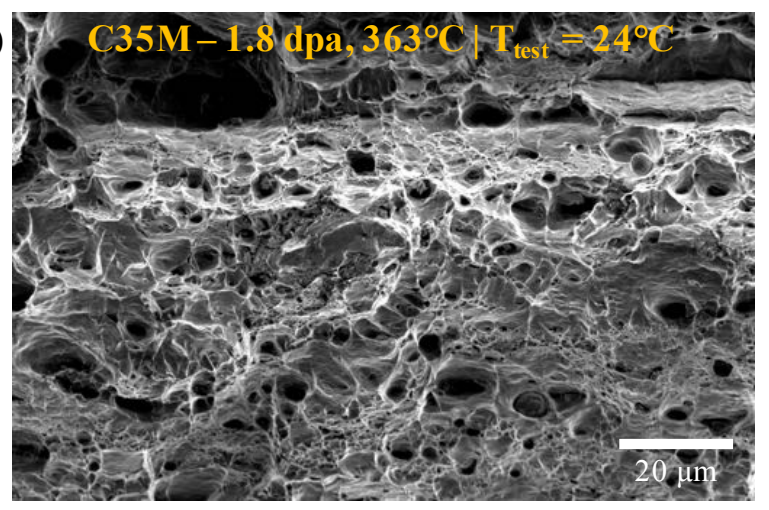

(f)

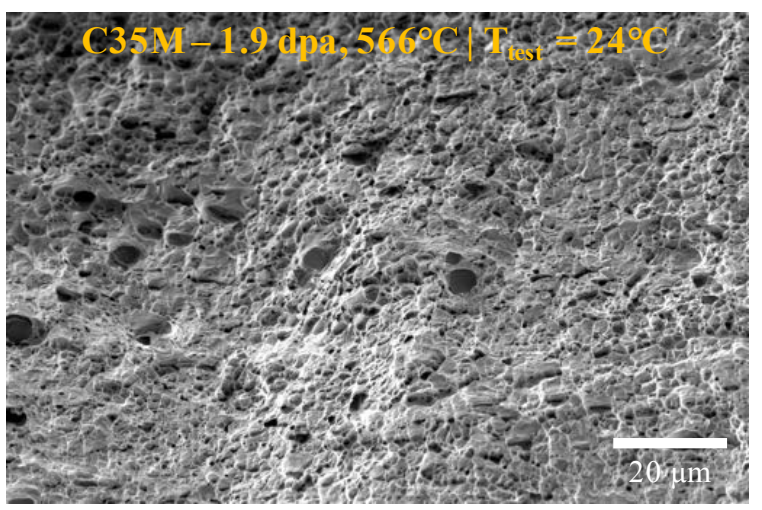

Figure 5. SEM micrographs (low and high magnification) showing the fracture surfaces after tensile testing in the irradiated condition for parent materials of $\mathrm{C} 35 \mathrm{M}$ : (a-b) $1.9 \mathrm{dpa}, 195^{\circ} \mathrm{C}$, (c-d) $1.8 \mathrm{dpa}, 363^{\circ} \mathrm{C}$, (e-f) 1.9 dpa, $566^{\circ} \mathrm{C}$. 
(a)

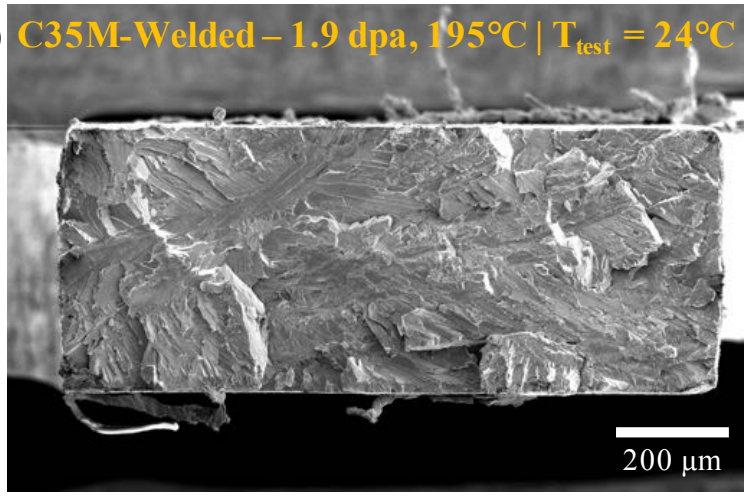

(c)

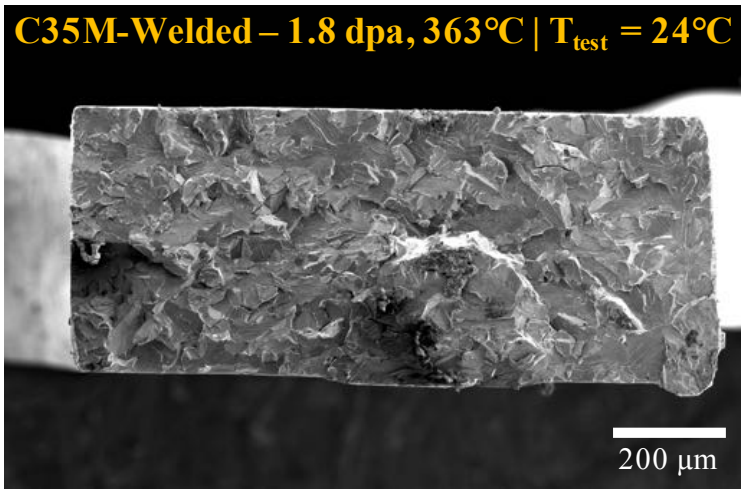

(e)

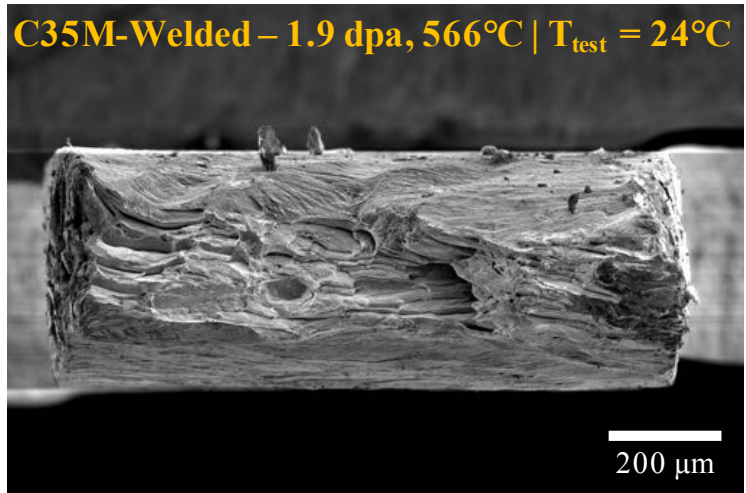

(b)

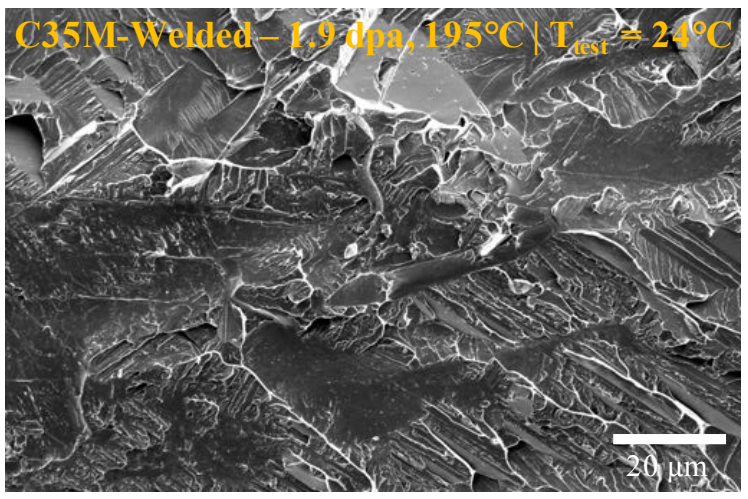

(d)

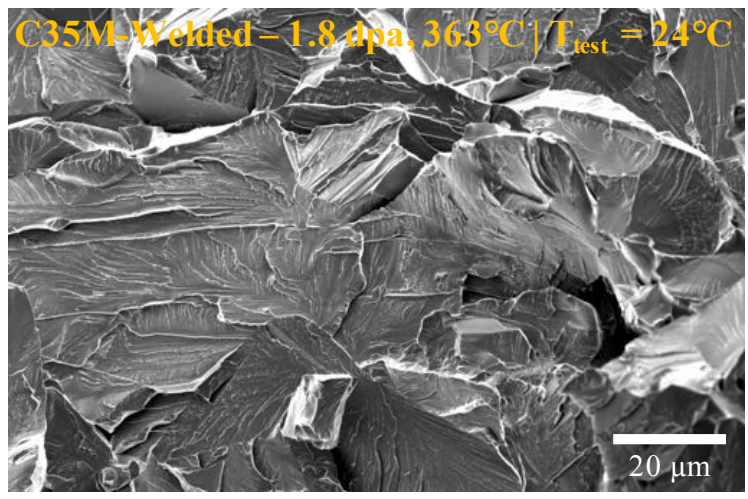

(f)

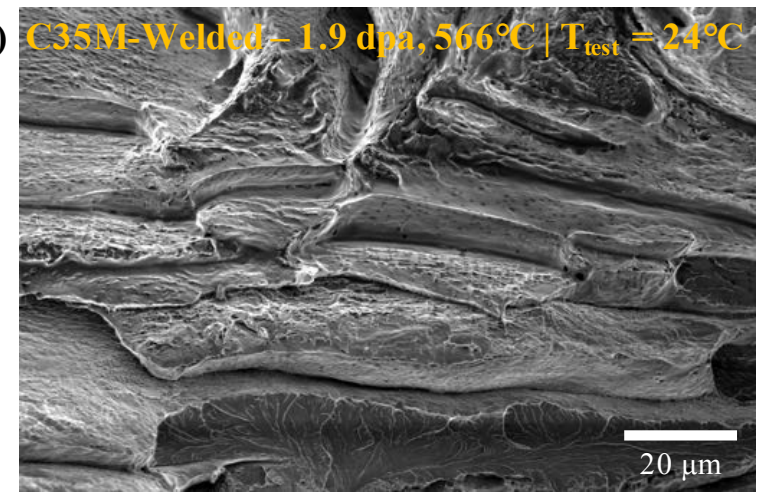

Figure 6. SEM micrographs (low and high magnification) showing the fracture surfaces after tensile testing in the irradiated condition for weldments of $\mathrm{C} 35 \mathrm{M}$ : (a-b) $1.9 \mathrm{dpa}, 195^{\circ} \mathrm{C},(\mathrm{c}-\mathrm{d}) 1.8 \mathrm{dpa}, 363^{\circ} \mathrm{C}$, (e-f) $1.9 \mathrm{dpa}$, $566^{\circ} \mathrm{C}$.

\subsection{Discussion of the preliminary data}

The mechanical properties after neutron irradiation in the base alloys tested in the SS-J2 geometry is in line with similar studies on other ferritic high-chromium $\mathrm{FeCr}$ alloys. For instance, conventional ferritic $\mathrm{FeCr}$ alloys, such as HT-9, have very strong sensitivity to irradiation temperature in regards to irradiation hardening [17]. The hardening is most pronounced when the irradiation temperature is $1 / 3$ of the melting temperature and the dose to saturate the mechanical properties increases with increasing irradiation temperature [17]. The lower temperature irradiations investigated here $\left(200^{\circ} \mathrm{C}\right.$ and $\left.330^{\circ} \mathrm{C}\right)$ are both below $1 / 3$ the melting point of the alloys $\left(\sim 1500^{\circ} \mathrm{C}\right)$ and significant radiation-induced hardening and embrittlement are observed. Typical saturation doses in conventional ferritic $\mathrm{FeCr}$ alloys exist near $10 \mathrm{dpa}$ 
when irradiated at temperatures of $300-400^{\circ} \mathrm{C}$. Due to the low doses investigated $(<2 \mathrm{dpa})$, the dose to saturation at different irradiation temperatures cannot be determined for the base $\mathrm{FeCrAl}$ alloys at this time.

The pronounced difference in response between the base alloy samples and the weldments suggests differences in either the deformation mechanisms or at a minimum an accelerated effect in the weldments. Prior work on $\mathrm{FeCr}$ and $\mathrm{FeCrAl}$ alloys have linked the observed hardening response to the radiationinduced microstructure including the formation of defects such as $a / 2\langle 111\rangle$ dislocation loops, $a\langle 100\rangle$ dislocation loops, black dot damage, and $\mathrm{Cr}$-rich $\alpha^{\prime}$ phase [5]. Dislocation loop and black dot formation have been shown to be microstructurally dependent but $\alpha^{\prime}$ formation has been indicate to have stronger ties to the initial composition of the alloy over the microstructure. In a study evaluating four model $\mathrm{FeCrAl}$ alloys that were neutron irradiated to $1.8 \mathrm{dpa}$ at $382^{\circ} \mathrm{C}$ [5], the hardening was determined to be primarly due to the $\mathrm{Cr}$-rich $\alpha^{\prime}$ phase due to the substantially higher number density of these precipitates compared to the formation of other radiation-induced defects.

The weldments in this study have pronounced differences in grain size compared to the base alloy, 25-75 $\mu \mathrm{m}$ compared to $10 \mu \mathrm{m}$ respectively. Seeing as prior studies have indicated that $\alpha^{\prime}$ formation is not strongly microstructurally dependent suggests a different hardening and embrittlement mechanism than previously determined for non-welded $\mathrm{FeCrAl}$ alloys. One possibility is the low defect sink density (i.e. large grain size and low dislocation density) in the fusion zone is strongly promoting radiation-induced segregation (RIS) which can embrittle grain boundaries. RIS could be further exacerbated by prior segregation due to welding, but grain boundary chemistry either before irradiation or after has not been completed to date. Another possibility is the lower sink density in the fusion zone is promoting larger densities of radiation-induced dislocation loops. Saturation of the defect loop structure could inhibit dislocation motion under stress, hence leading to higher embrittlement in the fusion zone versus the base metal. Clearly, further investigations are needed to build upon the work completed here to unanimously confirm the deformation modes and underlying mechanisms for the observed responses of the welded $\mathrm{FeCrAl}$ alloys. 


\section{MINIATURE SPECIMENS TESTED IN LAMDA}

\subsection{The development of the in-situ testing}

As was mentioned above, SS-2E (or SS-Mini) specimens were designated for mechanical testing at the ORNL LAMDA facility. After irradiation at $\sim 1.8-1.9 \mathrm{dpa}$, the activity level of the miniature samples was $\sim 50-60 \mathrm{mR} / 1 \mathrm{~h}$ at $30 \mathrm{~cm}$ allowing for their handling outside of the hot cell. The development of the SS-2E geometry pursued several goals.

First, modern mechanical test methods allow for non-contact strain measurement via digital image correlation (DIC) or laser speckle interferometry. This opens a possibility to track the appearance and evolution of deformation bands at the specimen surface and calculate strain field along the specimen gage [16]. In addition to the nominal engineering mechanical properties (see Section 4.3), true stress - true strain curves may be easy retrieved and analyzed. It is worth to note that very limited DIC data exist for irradiated materials, and no literature is available for irradiated FeCrAl alloys.

Second, recent progress in microstructural characterization methods opens a possibility to gain additional data using only one irradiated specimen. For instance, electron back scatter diffraction (EBSD) came in the material science practice about two decades ago. EBSD became a widely used characterization tool in materials science and that it has evolved to allow for more advanced investigations. For instance, highresolution EBSD (HR-EBSD) [18,19] allows for direct measurements of the acting stress and for calculating geometrically necessary dislocation density as it is sensitive to elastic strains[18]. At the moment, a limited number of publications are available for non-irradiated materials, and practically no work has been done for irradiated materials.

Third, potential areas of intereste can be studied by targeted microstructural analysis. If DIC provides data on the local strain distribution, the focused ion beam (FIB) may be used to get microstructural data connected to known strain and stress values. If SEM is employed to analyze strain-induced features, FIB and TEM will gain important new insights into the processes during straining. The advantages of this combination (Controlled straining $>$ SEM $>$ FIB $>$ TEM) were demonstrated previously for irradiated austenitic steels $[20,21]$.

Finally, some materials may demonstrate deformation-induced twinning during straining and plastic deformation; twinning was observed in several $\mathrm{FeCr}$ alloys [22]; twinning may happen in the $\mathrm{FeCrAl}$ alloys after irradiation, when high stress level may be easy reached due to radiation hardening. The common practice of post-deformation structure analysis postulates that there are no structure changes during unloading or such changes are negligible. However, this is not always true. For instance, Barnett et al. [19] conducted EBSD analysis of deformed Mg-3Al-1Zn alloy, and the EBSD measurements and scanning were conducted for the specimen during and after unloading. It was demonstrated that stress release led to de-twinning - that is, part of the deformation twins formed during straining disappeared during unloading [19]. Because of high yield stress in irradiated alloys, the elastic strains may be high enough to provide the driving force for dislocation channel evolution during unloading. This deformation mechanism is also important to investigate. If in-situ straining capability is available, one continuously deformed specimen will be able to provide data for a wide range of conditions (e.g. strain levels). This approach was successfully used for in-situ creep experiments [23] and precise strain and misorientation mapping [24], etc. 
Thus, it was important to establish the in-situ test capability and employ it for the current project. To perform this, the miniature tensile stage from Kammrath and Weiss Technologies, Inc., is being acquired in collaboration with other projects.

The selected model, MZ.Sb miniature tensile tester (Figure 7), has a loading capacity up to $5 \mathrm{kN}$, providing an opportunity to test not only miniature specimens offered here, but all specimen geometries available at LAMDA, and, in the future, compact tension specimens. Two load cells will be provided (2 $\mathrm{kN}$ and $5 \mathrm{kN}$ load range).
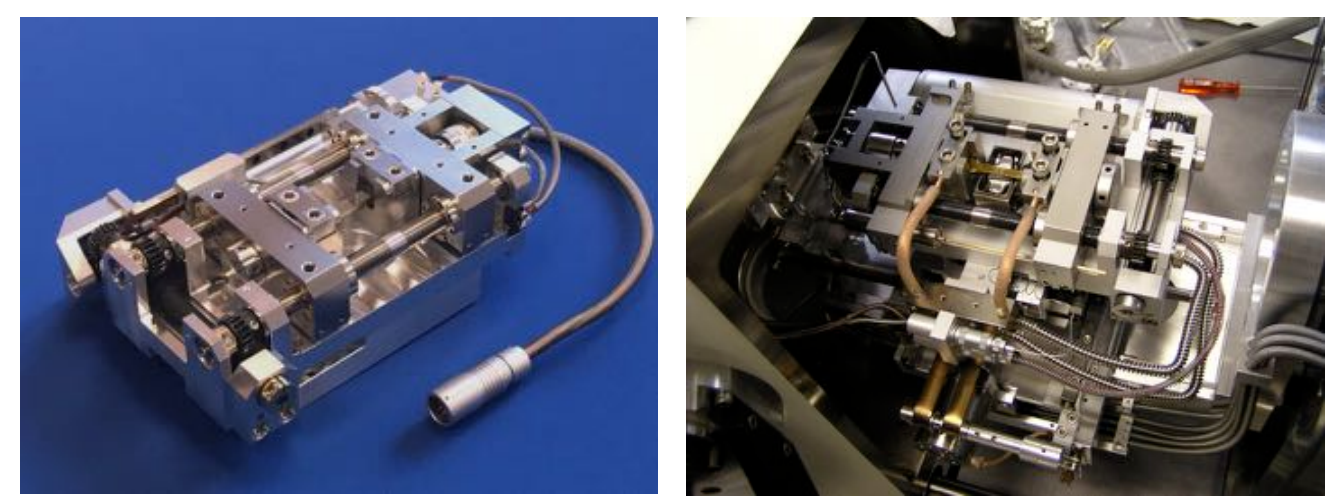

Figure 7. General view of the MZ.Sb small tensile stage for the VERSA 3-D SEM (left). Tensile stage with a high-temperature heater installed in the SEM microscope chamber (image provided by the vendor, Kammrath and Weiss Technologies, Inc.).

The small tensile frame is operated by a modern microprocessor controller that allows for a crosshead displacement range of 0.1 to $20 \mu \mathrm{m} / \mathrm{s}$. Two heating options will be available: a middle-temperature range (up to $320^{\circ} \mathrm{C}$, for the light-water reactor relevant conditions) and a high-temperature (up to $800^{\circ} \mathrm{C}$, for advanced alloy testing including the present project). The device is expected to be delivered, installed, and tested in November-December 2016.

\subsection{Specimen preparation procedure}

Using the benefits discussed above will require thoughtful specimen preparation and careful handling procedures for radioactive specimens. Specimen preparation methods should provide a clean, plastic strain- and defect-free surface. At the same time, the procedure should be simple and reasonably fast to minimize the radiological threat to the investigator. Specimen handling routines should keep the straininduced artifacts and other features of interest; however, it should not interfere and prevent the use of necessary test and measurement methods.

To produce specimens, the vendor used EDM followed by mechanical grinding to fit the dimensions. Grinding led to the formation of the deformed surface layer; however, this layer could not be removed prior to irradiation since it was critical to keep the irradiation capsule assembly mechanical integrity and thermal performance. Irradiation at the increased temperature may promote oxidation and, finally, specimen handling after irradiation will unavoidably lead to the occasional mechanical damage. Thus, some material thickness should be removed for each irradiated specimen to get a clean surface, but the layer being removed must be as thin as possible to maintain the specimen mechanical performance.

To estimate the thickness of the damaged surface layer, several non-irradiated specimens (companions to the irradiated ones) were epoxy-mounted and polished using standard metallographic procedures with colloidal silica as the final preparation step. The cross-sections were analyzed using SEM-EBSD. 
Figure 8 shows the EBSD data set for the specimen cross-section. One may see that strong plastic strain present in the near surface layer; The grain reference orientation deviation (GROD) value for the nearsurface grains reached up to $46^{\circ}$, indicating a high dislocation density and strain level.
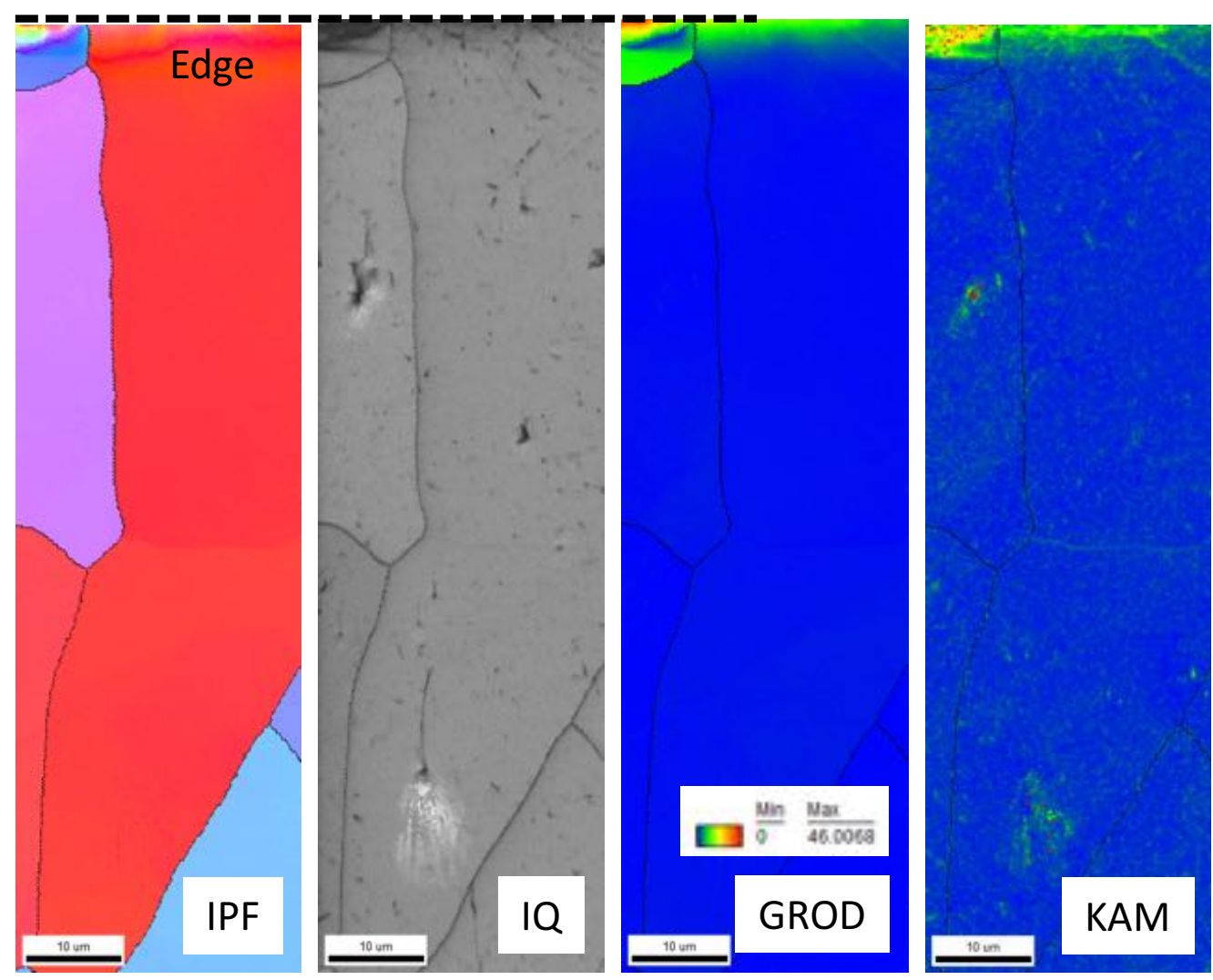

Figure 8. Representative EBSD data set (Inverse Pole Figure, IPF, Image Quality, IQ, Grain Reference Orientation Deviation, GROD, and Kernel Average Misorientation, KAM maps) for the specimen crosssection (weldment of C35M alloy). One may see the signs of pronounced cold work (orientation change in IPF maps and high local misorientation in the GROD and KAM maps) near the specimen surface (scan edge, top of image).

Figure 9 shows the KAM profiles. One can see KAM reached a maximum at the surface (up to 2-4 ${ }^{\circ}$ depending on the location), but quickly decreased with depth. Below 7-10 $\mu \mathrm{m}$ the KAM values saturated at $\sim 0.4-0.6^{\circ}$ which was a typical bulk value for the given specimen. Therefore, removal of $\sim 10-15 \mu \mathrm{m}$ from the surface layer will be sufficient to eliminate any artifacts related to the specimen production. 

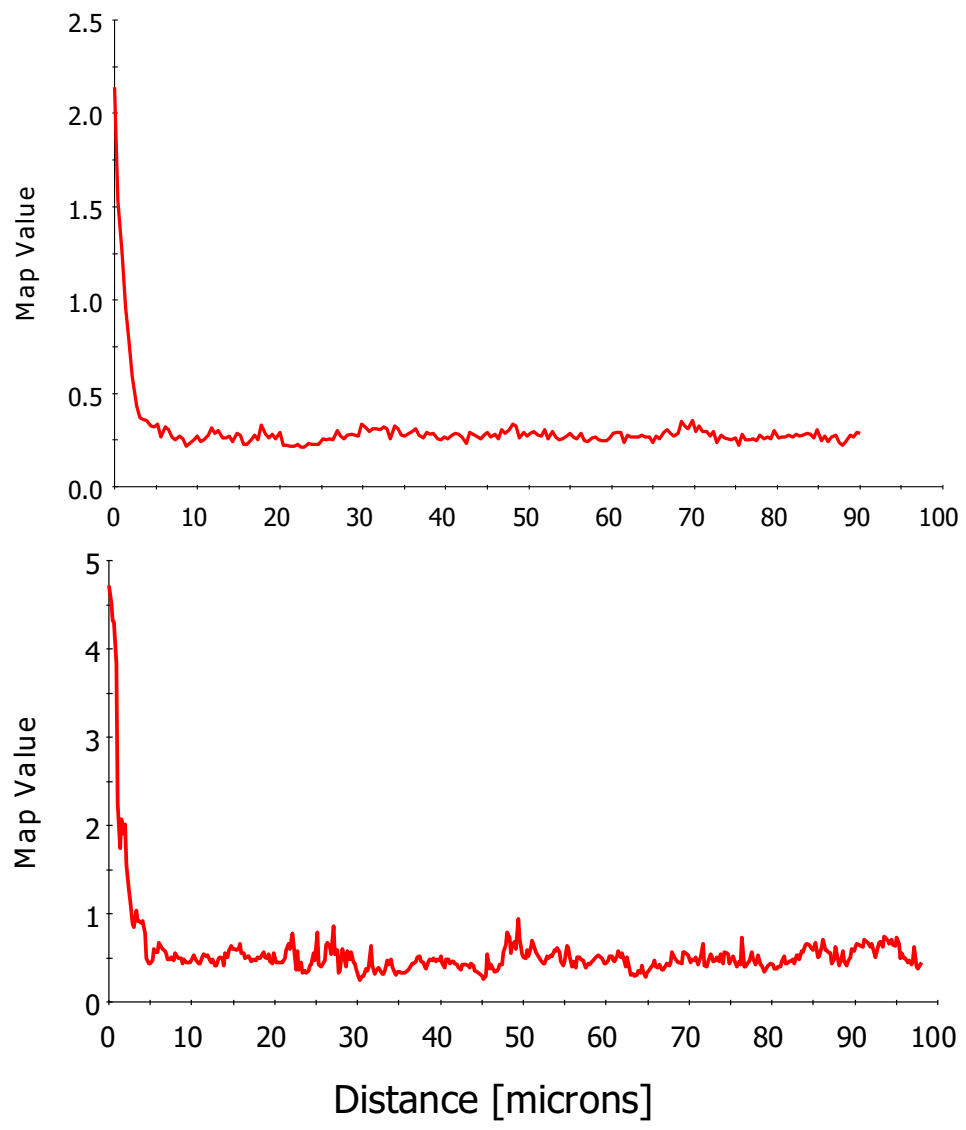

Figure 9. KAM profiles from two different locations as a function of depth (distance from the surface). KAM profiles averaging width: 20 data points.

Also, it was important to demonstrate that one specimen may provide a full data set starting with tensile testing (engineering tensile curve, DIC data) via surface evolution and morphology analysis and EBSD data for the deformed structure (both surface and the bulk). To achieve that, the non-irradiated SS-2E miniature tensile was mechanically polished from one side. 3- $\mu \mathrm{m}$ diamond sandpaper was used to remove $\sim 15 \mu \mathrm{m}$ layer from one specimen side. A Buehler Minimet unit allowed for fast polishing while keeping the specimen flat. The next preparation step included electropolishing for getting a clean, strain- and oxide-free surface. Electropolishing was performed using Struer A2 solution at 30 V DC for 3 seconds. The electropolishing step removed an approximately $10 \mu \mathrm{m}$ depth of material, so the prepared surface was considered cold-work free and feasible for EBSD analysis.

To perform the tensile test, the flat side of the tensile sample opposite to the electropolishing surface was painted with random black and white speckle pattern as shown in Figure 14 to provide DIC strain measurements. The prepared specimen was tensile tested at room temperature with a strain rate of $10^{-3} \mathrm{~s}^{-1}$. The specimen was handled using tweezers with soft plastic tips to avoid occasional mechanical damage. The soft plastic film was used to minimize contact between grips and the electropolished specimen surface. After the test, the DIC paint layer was removed, and the specimen was cleaned.

The electropolished surface was investigated using SEM-EBSD to analyze the strain-induced changes (appearance of slip lines and strain-induced relief, crack formation, etc.). Figure 10 and Figure 11 show some typical strain-induced features; several cracks were observed near the inclusions. Surprisingly, slip 
lines in the non-irradiated $\mathrm{C} 35 \mathrm{M}$ alloy (body-centered cubic (BCC) lattice) are not so pronounced compared to common face-centered cubic (FCC) materials, like austenitic steels. To reveal slip lines, a high tilt angle $\left(70^{\circ}\right)$ was necessary.
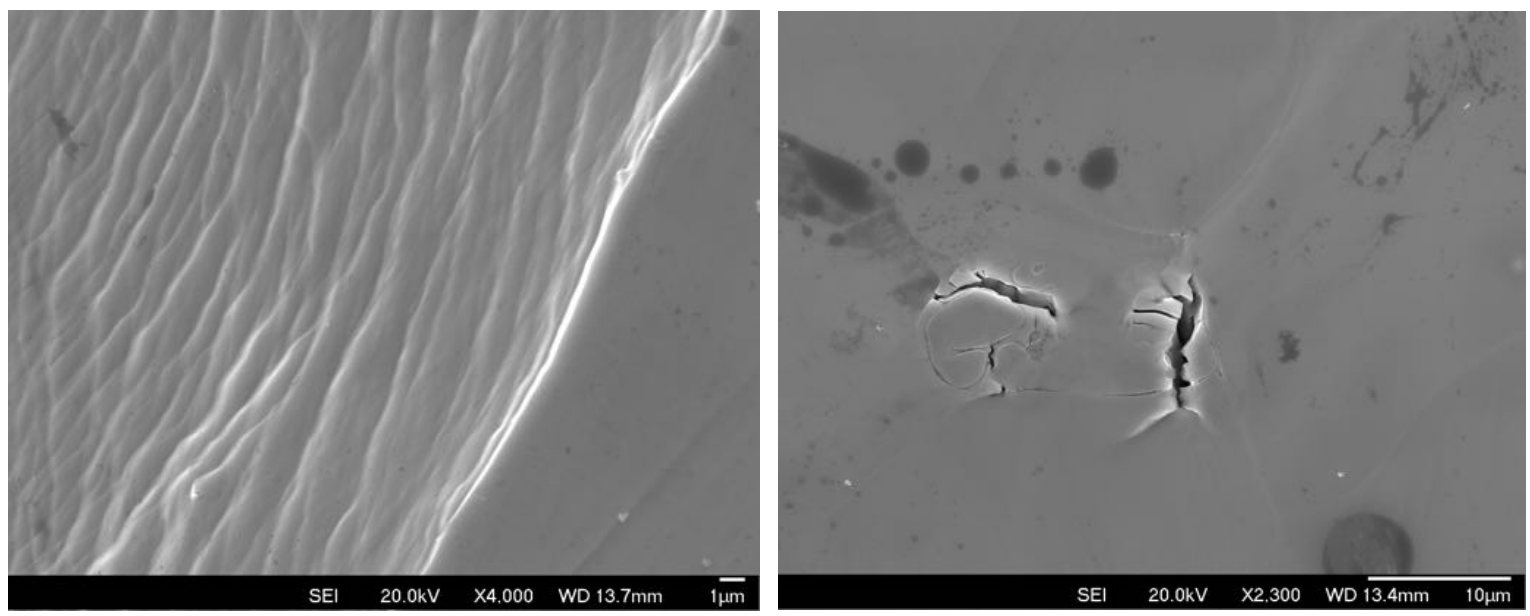

Figure 10. Left: Strain-induced relief near the fracture location $(\sim 50 \mu \mathrm{m}$ from the fracture point). Right: cracks associated with inclusions; grain boundaries are also visible. $0^{\circ}$-tilt.
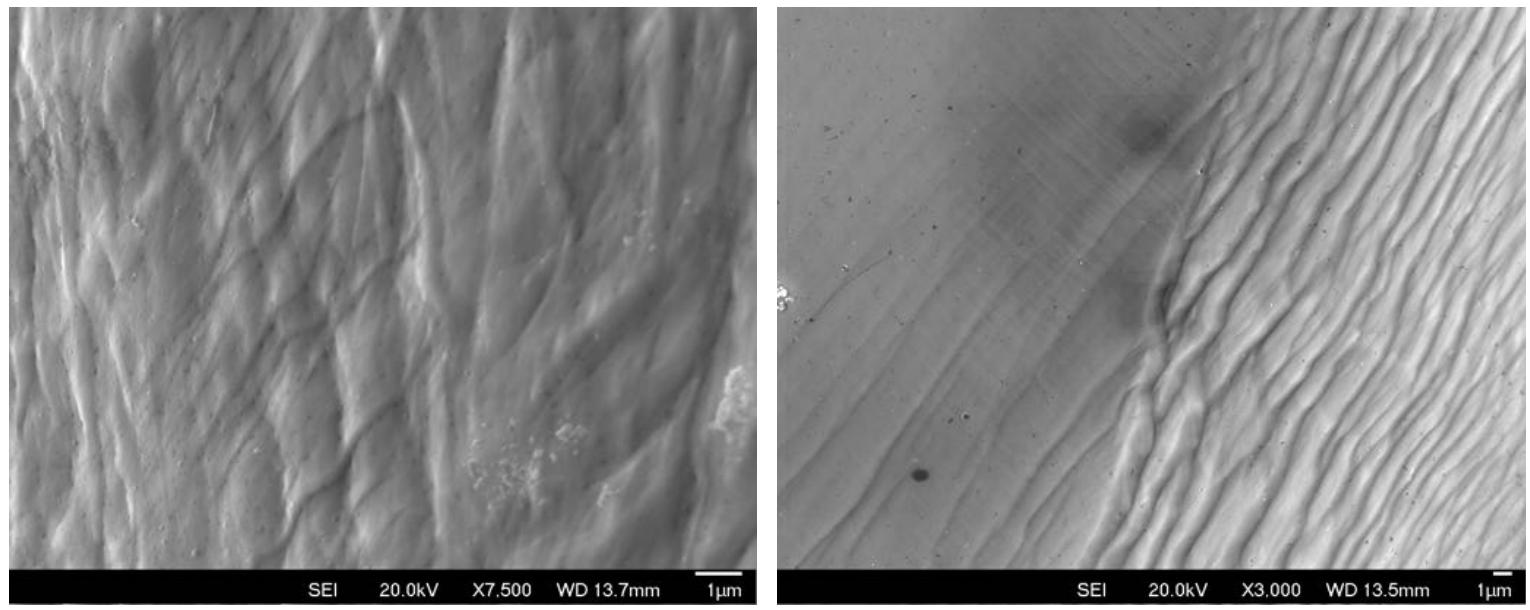

Figure 11. Strain-induced relief near the fracture location (maximum strain level). $\mathbf{7 0}^{\circ}$-tilt.

Figure 12 shows EBSD data set for the deformed specimen. The EBSD data had high enough quality. Fraction of bad points did not exceed $\sim 1-2 \%$ for performed scans, even for ones performed close to the fracture location with the highest strain level.

Most interestingly, the recorded EBSD patterns (Figure 13) after deformation did not demonstrate degradation, as was expected. Usually, for example in deformed austenitic steels, plastic strain and defect accumulation leads to strong pattern quality degradation even after modest plastic strain (e.g., 20-30\%). Starting at some strain level, it is often impossible to get reliable patterns, necessitating a very low scan rate in order to perform acceptable quality indexing. However, in the weldment of the C35M FeCrAl alloy, EBSD patterns recorded near the fracture point had high enough quality, comparable to the aswelded, non-deformed material. Thus, it was demonstrated that one miniature specimen may provide necessary data (tensile, DIC, EBSD, SEM) and may be used later to perform FIB lift-outs for deformation 
mechanism(s) analysis.
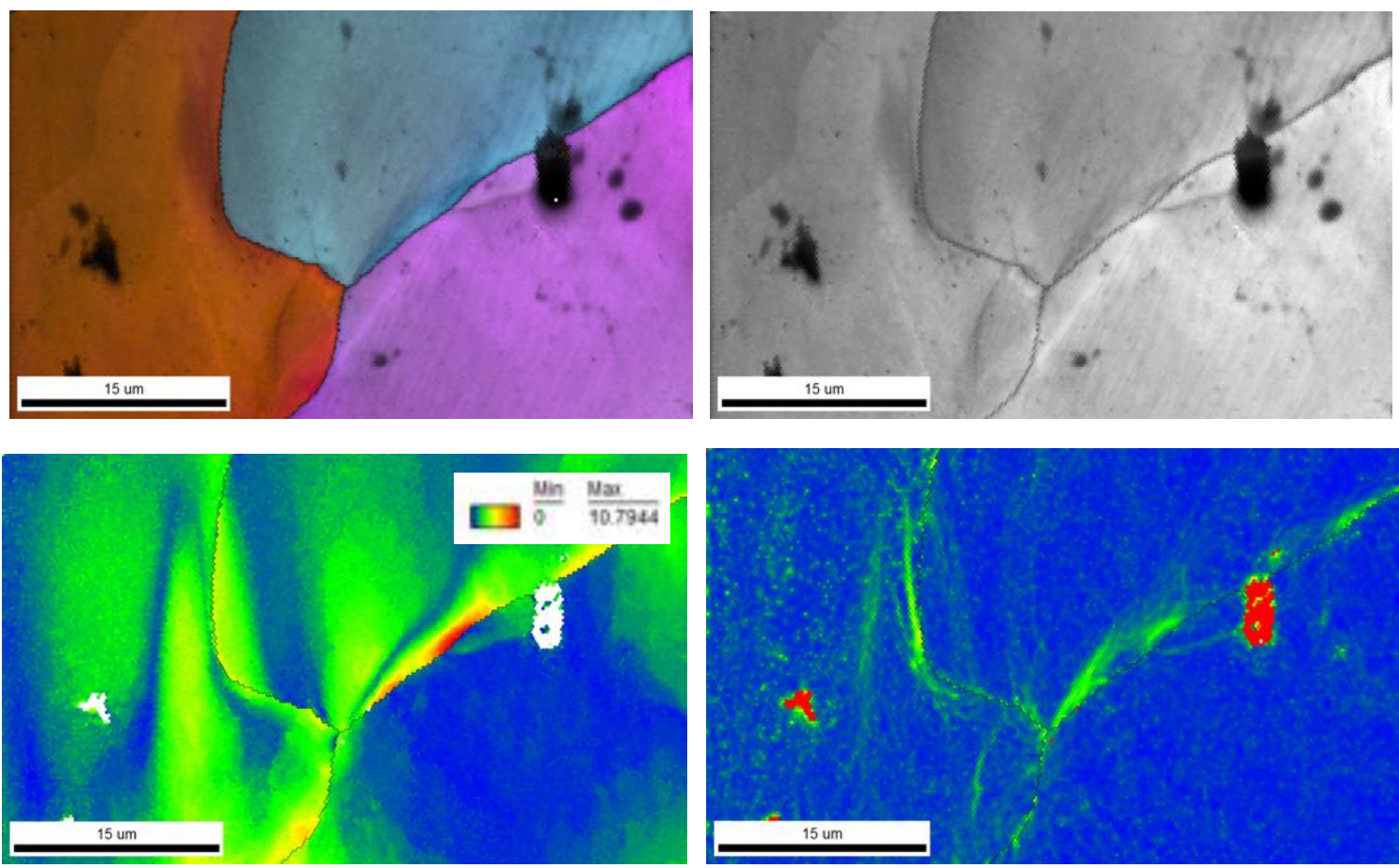

Figure 12. EBSD data set for the specimen surface after deformation. The scan was taken near the fracture location with a scanning rate of $\sim 57$ points per second, i.e. usual rate. Top left, IPF; top right IQ; bottom left, GROD; bottom right, KAM.

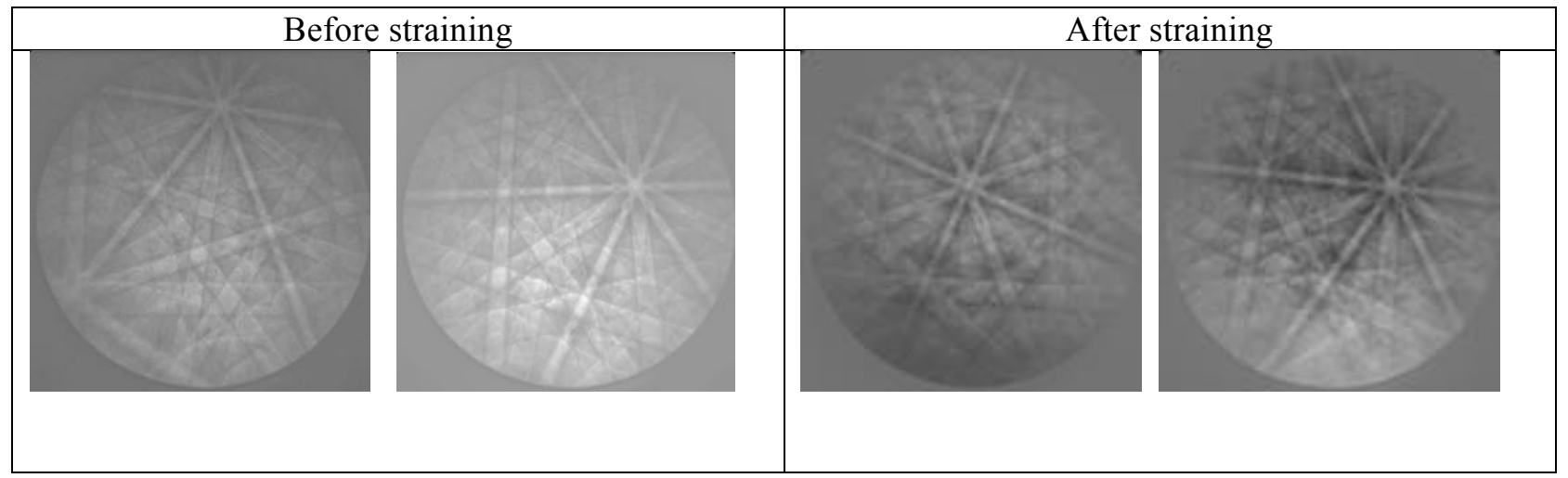

Figure 13. Representative EBSD patterns recorded for the same specimen before (left) and after (right) plastic deformation. Using DIC data, local strain level was estimated as $\sim 0.2-0.3$ in true strain units (Hencky's strain). 


\subsection{The preliminary mechanical testing results of irradiated SS-2E specimens}

Four irradiated C35M specimens were selected for the first round of the mechanical testing at the LAMDA. The number of specimens was limited due to the radiological inventory limitations in LAMDA at the time of testing; a number of other projects being performed at the same time led to the increased background radiation and did not allow for more specimens to be prepared and tested. Sample preperation was completed using the aforementioned methodology.

Tensile tests for SS-2E specimens were performed at room temperature in the LAMDA contamination zone, using a MTS two-column tensile screw machine. SS-2E specimen volumes were small enough that the radioactivity was below the limits for handling and sample preparation in a non-shielded laboratory. Prior to tensile testing the specimens were mechanically polished followed by light electropolishing to remove any deformation-induced layer from sample fabrication; the specimen preparation will be discussed in detail in Section 4.2. All tests were performed using shoulder loading with a strain rate of $\sim 10^{-3} \mathrm{~s}^{-1}$. Specimens were painted with a random speckle pattern, Figure 14, to provide optical, noncontact strain measurements during tensile tests [16]. During the tensile test, images were recorded at a rate of one frame per second. Strain-field and true stress-strain curves were determined using VIC2D commercial software and a custom program using common digital image correlation (DIC) algorithms.

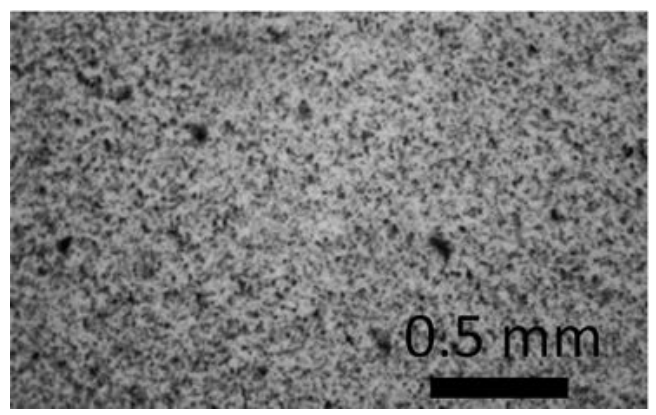

Figure 14. Image demonstrating the DIC pattern density and quality

Table 3 shows the mechanical properties of the miniature SS-2E specimens tested at LAMDA in comparison with the SS-J2 specimens tested at the hot cell facility. As follows from the results, there was a good enough agreement between the standard SS-J2 and miniature specimens; the difference in yield and ultimate stress was, in general, below $10 \%$. Some variation in the mechanical properties is expected due to differences in the irradiation temperature within the capsule, as stated previously, in addition to samples being extracted from different locations on the FeCrAl sheet production, which could have slight variations in warm-rolling conditions. Finally, additional variation could be present due to differences in the specimen geometries. In general, variation below $10 \%$ can be considered as sufficient matching between LAMDA and hot cell facility testing conditions and specimens.

Unfortunately, it appears the A03 specimen was misidentified; welded specimens irradiated at $\sim 364^{\circ} \mathrm{C}$ demonstrated zero or almost zero ductility while tested at the hot cell. The same low ductility was expected for the A03 specimen; however, it showed high enough uniform and total elongation, not a brittle fracture. The IDs of the non-tested specimens will be verified later, and the correct dose and irradiation temperature records with this object will be retrieved. 
Table 3. Mechanical properties for SS-2E specimens vs. SS-J3 (dose 1.8-1.9 dpa)

\begin{tabular}{|c|c|c|c|c|c|c|c|c|c|}
\hline \multirow{2}{*}{$\begin{array}{c}\text { Miniature } \\
\text { specimen } \\
\text { ID }\end{array}$} & $\begin{array}{c}\text { Irradiation } \\
\text { temp., }\end{array}$ & \multicolumn{4}{|c|}{ SS-2E (Miniature specimen) } & \multicolumn{3}{|c|}{ SS-J2 geometry (testing at the hot cell) } \\
\cline { 3 - 11 } & $\begin{array}{c}\text { Yield } \\
\text { stress, } \\
\text { MPa }\end{array}$ & $\begin{array}{c}\text { Ult. } \\
\text { stress, } \\
\text { MPa }\end{array}$ & $\begin{array}{c}\text { Uniform } \\
\text { elong., } \\
\%\end{array}$ & $\begin{array}{c}\text { Total } \\
\text { elong., } \\
\%\end{array}$ & $\begin{array}{c}\text { Yield } \\
\text { stress, } \\
\text { MPa }\end{array}$ & $\begin{array}{c}\text { Ult. } \\
\text { stress, } \\
\text { MPa }\end{array}$ & $\begin{array}{c}\text { Uniform } \\
\text { elong., } \\
\%\end{array}$ & $\begin{array}{c}\text { Total } \\
\text { elong., } \\
\%\end{array}$ \\
\hline F03 & 330 & 914 & 937 & 2.7 & 10.4 & 903 & 944 & 4.2 & 11.5 \\
\hline F06 & 550 & 602 & 734 & 12.3 & 20.8 & 585 & 725 & 12.6 & 20.4 \\
\hline A03 & 330 & 625 & 703 & 4.0 & 12.1 & 923 & 926 & 0.4 & 0.8 \\
\hline A06 & 550 & 442 & 545 & 6.3 & 14.5 & 423 & 511 & 5.7 & 10.8 \\
\hline
\end{tabular}

\subsubsection{Non-welded specimens}

Figure 15 demonstrates an example of DIC data and Figure 16 shows strain distribution along the irradiated F03 specimen gage. Frame \#60 was taken near the yield stress limit showing uniform strain with a weak localization area (black arrow) near the specimen head, as shown in Figure 16. As plastic deformation progressed (frame \#70), strain distribution along the gage became more uniform. Frame \#90, Figure 16, was taken soon after the ultimate stress point, and one can see the beginning of neck development. Frame \#110, made during the necking, shows the development of neck. Nevertheless, plastic strain out of neck still progressed: the areas far from the neck experienced some small increase in the strain level (see the strain distribution curves for Frames \#90 and \#110).

Figure 17 shows strain distribution along the irradiated F06 specimen gage; in contrast to the previous specimen, F06 was irradiated at elevated temperature $\left(\sim 550^{\circ} \mathrm{C}\right)$ and demonstrated weak or no radiation hardening. As follows from the results, a plastic strain developed along the gage in a uniform manner (Frames \#60,\#100, and \#140). After the ultimate stress point had been reached, the neck began to form (Frame \#180) leading to a strong increase in the local strains (Frame \#210). 
Frame \#1

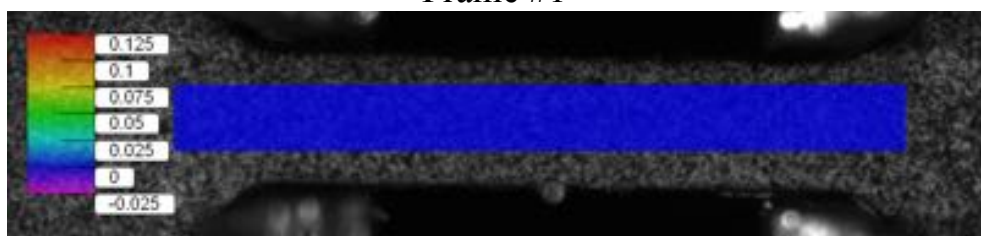

Frame \#70
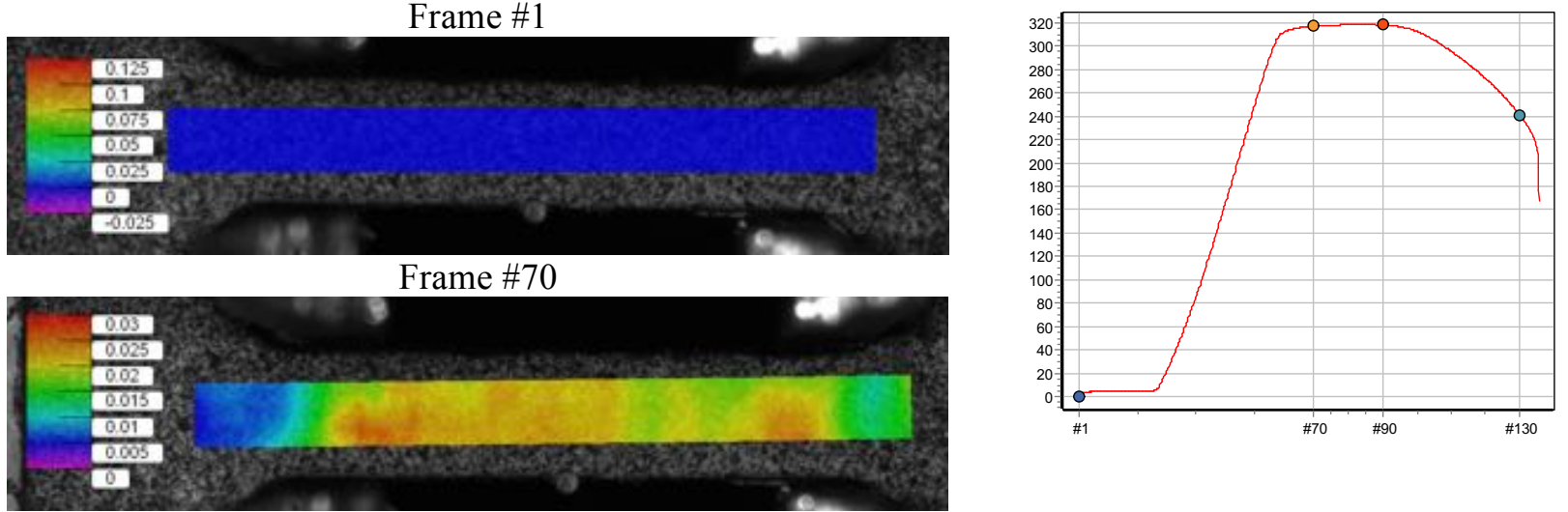

Frame \#90

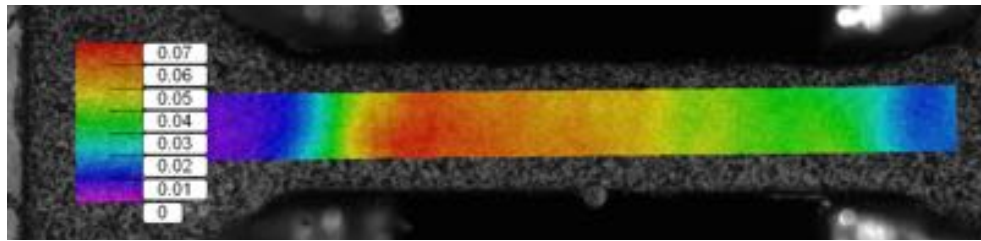

Frame \#130

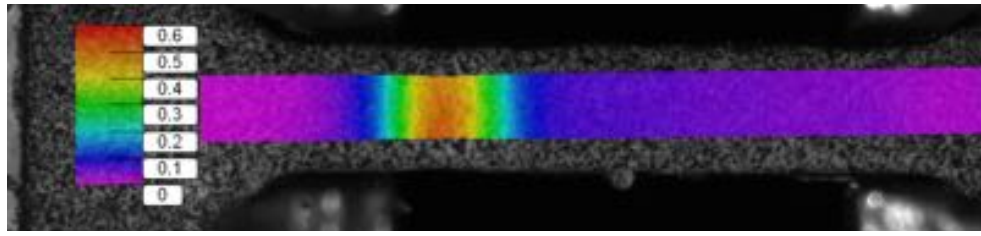

Figure 15. Several frames taken during the tensile test (non-welded F03 specimen) with color maps showing strain distribution (Green-Lagrange strain tensor). Insertion at the right shows raw tensile data (load, $\mathrm{N}$ vs experiment time). 


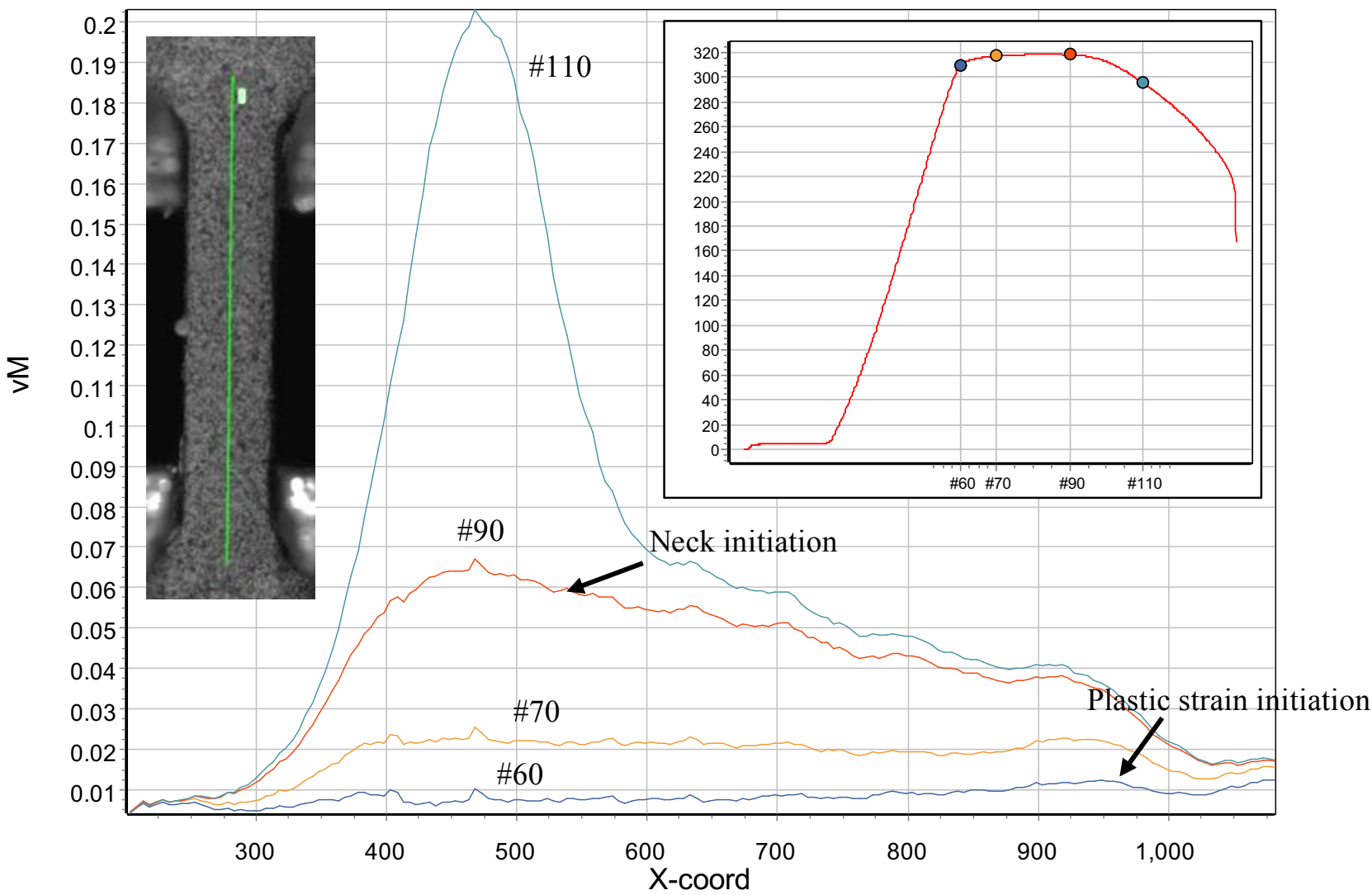

Figure 16. Strain distribution along the gage for the F03 specimen. Insertion at the left shows the image of the specimen prior to testing. The inserted diagram at the right demonstrates the tensile diagram and the location of the DIC frames (\#60, \#70, etc.). The main plot shows von Mises strain (vM); Green-Lagrange tensor was employed. The results may be expressed using any strain metric (engineering strain or true strain); however, Green-Lagrange strain definition is the most common one for DIC. 


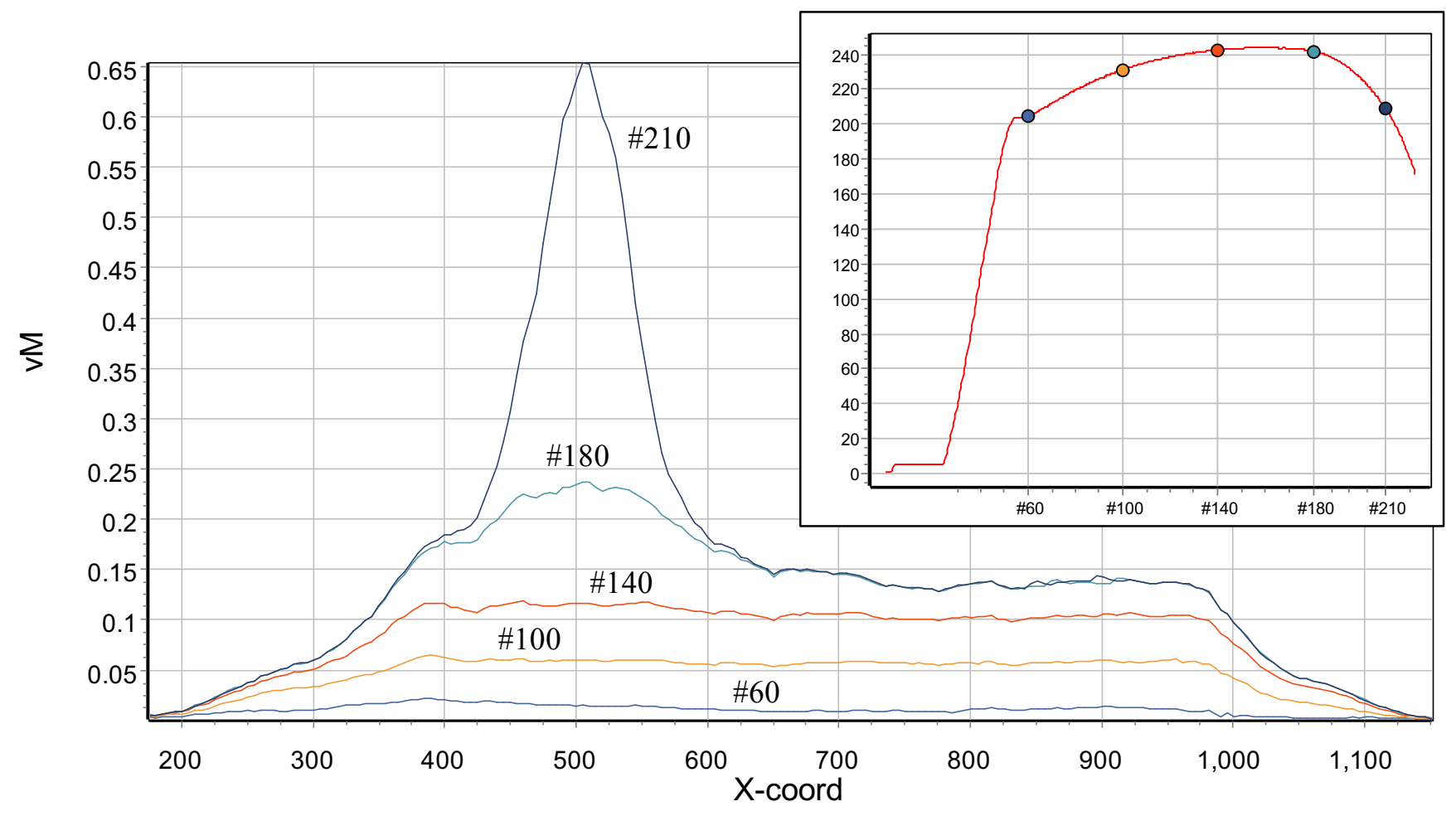

Figure 17. Strain distribution (von Mises strain, vM, developed from Green-Lagrange tensor) along the gage for the F06 specimen. The inserted diagram at the right demonstrates the tensile curve and the location of the DIC frames (\#60, \#100, etc.).

\subsubsection{Welded A06 specimen}

Figure 18 shows the strain distribution along the gage of the irradiated welded specimen (A06); in contrast to the non-welded one (F06 in Figure 17), strain distribution appears to be strongly non-uniform immediately after yield stress (Frame \#60). Two local strain maximums are visible (black arrows), and one more may be suggested later (see strains distribution curve for Frame \#100). Most likely these maximums correspond to the heat affected zones near the weldment and the middle of the weldment. As the test progressed, a neck formed and fracture happen in one of these local strain extremums (see the strain distribution curve for Frame \#120).

Thus, as follows from the results, performing tensile tests with DIC provides additional important information on strain distribution; local hardening behavior and local yield stress distribution data can also be retrieved and analyzed.

Strain distribution along the gage (Figure 16, Figure 17, Figure 18) may be significantly non-uniform, especially for the welded objects (Figure 18), and DIC allows for further targeted analysis of different locations. For example, the same specimen may be prepared for EBSD scanning and after that, the EBSD strain metrics, like KAM or GROD, will be compared with a real, measured strain value, not one calculated from the engineering curve. As believed, the FIB-TEM analysis will also benefit from having a detailed history for each object. 


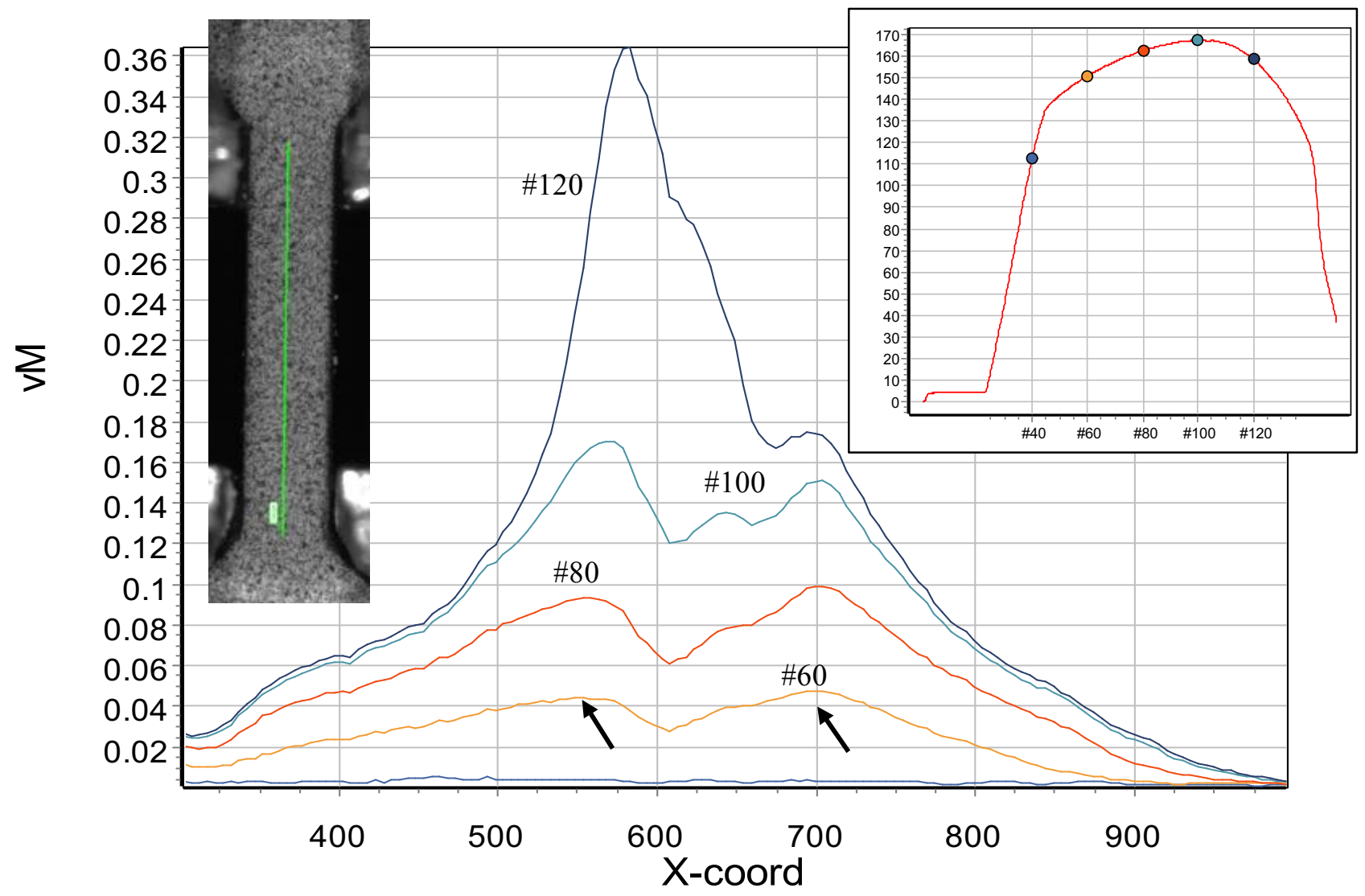

Figure 18. Strain distribution (von Mises strain, Green-Lagrange tensor) along the gage for the A06 (welded) specimen (see insertion at the left). The diagram at the right demonstrates the tensile curve for this specimen and the location of the DIC frames (\#40, \#60, etc.).

\subsubsection{Strain rate maps before and after welding in irradiated specimens}

Additional insight into the strain-induced phenomena may be gained using strain rate maps (Figure 19) generated using DIC data. These maps show how fast the local strain value changed at any given location during the experiment (with time). As follows from the map, no or very limited strain occurs below the yield stress limit (YS and lower dashed line in Figure 19). After that, non-welded specimen (F06) shows fairly uniform strain rate field with values around $\sim 0.001 \mathrm{~s}^{-1}$ (i.e., nominal strain rate). During necking, strain localizes in one area in the left portion of the specimen.

In contrast, the welded A06 specimen showed two local strain rate maximums and even after yield stress point the strain rate distribution was not uniform. This information, together with final local strain value, may allow for strain rate effect analysis. Some BCC-materials, like iron, may be sensitive to the strain rate especially at the elevated temperature; so knowing strain rate may be important for the $\mathrm{FeCrAl}$ alloys studied here. 


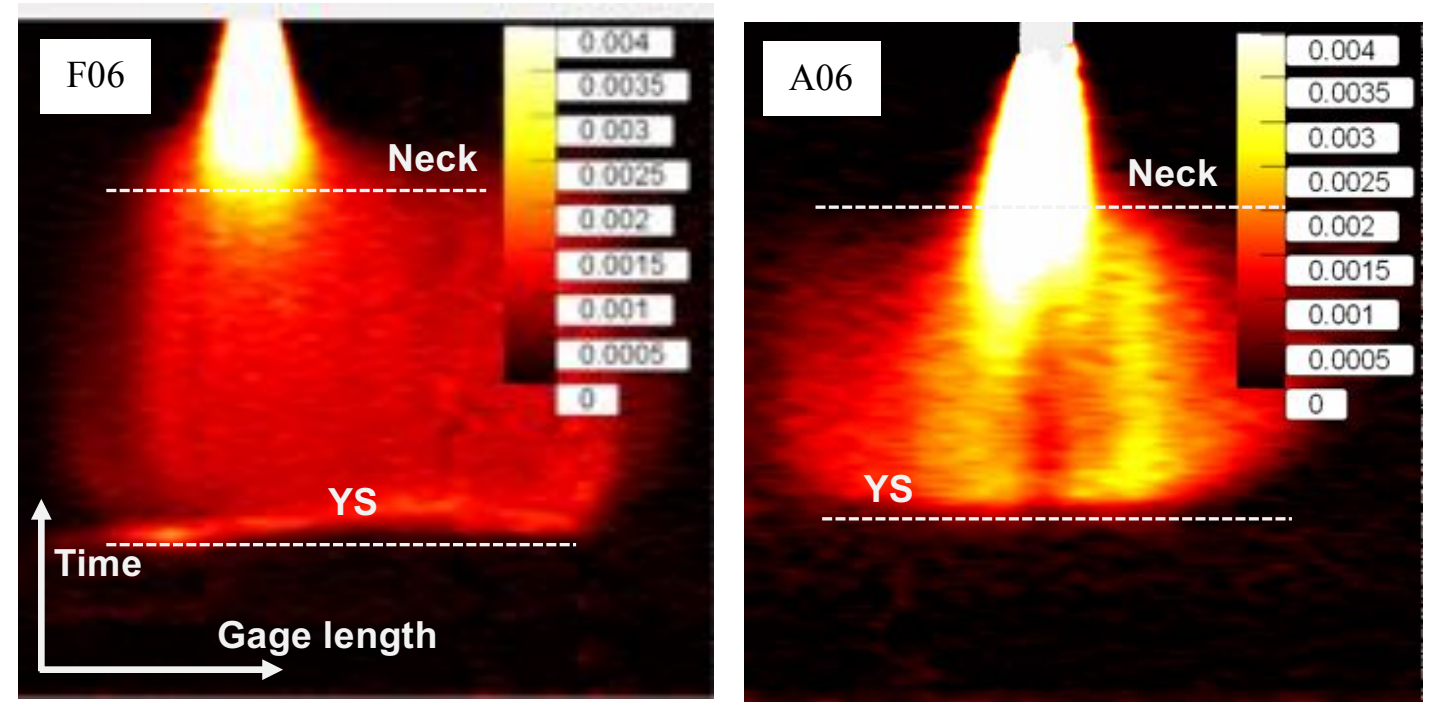

Figure 19. Strain rate maps for F06 (non-welded) and A06 (welded) specimens. YS and Neck show the offset plastic yielding and necking, respectively.

\section{CONCLUSIONS}

The present project explores the possibility to mitigate the welding-induced cracking - one of the general issues associated with $\mathrm{FeCrAl}$ alloys - via alloying and precise microstructure control of the weldments. In the frame work of the project, several advanced alloys were developed and are being investigated. For the first time, neutron irradiation and post-irradiation analysis were performed on welded $\mathrm{FeCrAl}$ alloy specimens.

The report provides preliminary, working results on the post-irradiation characterization and mechanical tests performed during FY2016. First, tensile tests with SS-J2 type specimens were conducted in a hot cell facility. The most important finding is weak radiation hardening in the specimens irradiated at $550^{\circ} \mathrm{C}$. The decrease of the irradiation temperature led to the increase of radiation hardening degree and strong embrittlement. The radiation embrittlement was more pronounced in the welded specimens, which demonstrated, according to the fractography results, completely brittle, river-like fracture surfaces.

Additionally, tensile tests were performed in the LAMDA facility using the purposefully designed small specimen geometry (SS-2E). The capability to conduct modern, instrumented tensile tests was successfully demonstrated allowing for detailed analysis of strain and stress distributions in the irradiated deformed specimens, including the base and weldment FeCrAl alloys. Plastic strain initiation and necking were analyzed in detail; the concept of strain rate maps was introduced and discussed.

The present work highlights the preliminary data on the PIE completed within the context of this program. Further PIE is planned including extensive microstructural investigations using modern techniques such as SEM-EBSD and TEM. Particular attention will be paid towards the underlying microstructures and deformation mechanisms leading to severe embrittlement in the FeCrAl weldments. Additionally, higher dose specimens are anticipated to become available within the timeframe of this program and additional PIE will be conducted on these specimens to establish not only irradiation temperature trends but irradiation dose trends as well. 


\section{REFERENCES}

[1] S.J. Zinkle, K.A. Terrani, J.C. Gehin, L.J. Ott, L.L. Snead, Accident tolerant fuels for LWRs: A perspective, J. Nucl. Mater. 448 (2014) 374-379. doi:10.1016/j.jnucmat.2013.12.005.

[2] K.A. Terrani, S.J. Zinkle, L.L. Snead, Advanced oxidation-resistant iron-based alloys for LWR fuel cladding, J. Nucl. Mater. 448 (2013) 420-435. doi:10.1016/j.jnucmat.2013.06.041.

[3] B.A. Pint, K.A. Unocic, K.A. Terrani, The effect of steam on the high temperature oxidation behavior of alumina-forming alloys, Mater. High Temp. 32 (2014) 28-35.

[4] B.A. Pint, K.A. Terrani, M.P. Brady, T. Cheng, J.R. Keiser, High temperature oxidation of fuel cladding candidate materials in steam-hydrogen environments, J. Nucl. Mater. 440 (2013) 420 427. doi:10.1016/j.jnucmat.2013.05.047.

[5] K.G. Field, X. Hu, K.C. Littrell, Y. Yamamoto, L.L. Snead, Radiation tolerance of neutronirradiated model Fe-Cr-Al alloys, J. Nucl. Mater. 465 (2015) 746-755. doi:10.1016/j.jnucmat.2015.06.023.

[6] P.D. Edmondson, S.A. Briggs, Y.Yamamoto, R.H. Howard, K. Sridharan, K.A. Terrani, et al., Irradiation-enhanced $\alpha^{\prime}$ precipitation in model FeCrAl alloys, Scr. Mater. 116 (2016) 112-116. doi:10.1016/j.scriptamat.2016.02.002.

[7] E.A. Little, D.A. Stow, Void-swelling in irons and ferritic steels, J. Nucl. Mater. 87 (1979) 25-39.

[8] J.N. Dupont, J.R. Regina, K. Adams, Improving the weldability of fecral weld overlay coatings, Foss. Energy Mater. Conf. (2007) 131-137.

[9] J.R. Regina, J.N. Dupont, A.R. Marder, The effect of chromium on the weldability and microstructure of Fe-Cr-Al weld cladding, Weld. J. 86 (2007) 170-178.

[10] J. Tusek, A. Kosmac, U. Nartnik, A. Dejan, Welding of heat-resistant $20 \% \mathrm{Cr}-5 \% \mathrm{Al}$ steels, Z. Met. 93 (2002) 310-314.

[11] E.M. El-Giar, M.A. Zaeem, H. El Kadiri, R.S. Florea, H. Rhee, Y. Bienvenu, et al., On laser welding of thin steel sheets, Sci. Technol. Weld. Join. 17 (2012) 571-580. doi:10.1179/1362171812y.0000000050.

[12] K.G. Field, M.N. Gussev, Y. Yamamoto, L.L. Snead, Deformation behavior of laser welds in high temperature oxidation resistant $\mathrm{Fe}-\mathrm{Cr}-\mathrm{Al}$ alloys for fuel cladding applications, J. Nucl. Mater. 454 (2014) 352-358. doi:10.1016/j.jnucmat.2014.08.013.

[13] K.G. Field, M.N. Gussev, R. Howard, First Annual Progress Report on Radiation Tolerance of Controlled Fusion Welds in High Temperature Oxidation Resistant FeCrAl Alloys, ORNL/TM2015/770. (2015).

[14] K.G. Field, R.H. Howard, Y. Yamamoto, Design of Experiment for Irradiation of Welded Candidate Fe-Cr-Al Alloys, ORNL/TM-2015/375. (2015).

[15] A.A. Campbell, W.D. Porter, Y. Katoh, L.L. Snead, Method for analyzing passive silicon carbide thermometry with a continuous dilatometer to determine irradiation temperature, Nucl. Instruments Methods Phys. Res. Sect. B Beam Interact. with Mater. Atoms. 370 (2016) 49-58. doi:10.1016/j.nimb.2016.01.005.

[16] M.A. Sutton, J.J. Orteu, H. Schreier, Image Correlation for Shape, Motion and Deformation Measurements: Basic Concepts, Theory and Applications, Springer Science \& Business Media, 2009. https://books.google.com/books?hl=en\&lr=\&id=AlkqMxpQMLsC\&pgis=1 (accessed 
December 22, 2015).

[17] O. Anderoglu, T.S. Byun, M. Toloczko, S.A. Maloy, Mechanical Performance of Ferritic Martensitic Steels for High Dose Applications in Advanced Nuclear Reactors, Metall. Mater. Trans. A. 44 (2013) 70-83. doi:10.1007/s11661-012-1565-y.

[18] T.B. Britton, J. Jiang, R. Clough, E. Tarleton, A.I. Kirkland, A.J. Wilkinson, Assessing the precision of strain measurements using electron backscatter diffraction - Part 2: Experimental demonstration, Ultramicroscopy. 135 (2013) 136-141. doi:10.1016/j.ultramic.2013.08.006.

[19] M.R. Barnett, Z. Keshavarz, M.D. Nave, Microstructural features of rolled Mg-3Al-1Zn, Metall. Mater. Trans. A. 36 (2005) 1697-1704. doi:10.1007/s11661-005-0033-3.

[20] K.G. Field, M.N. Gussev, J.T. Busby, Microstructural Characterization of Deformation Localization at Small Strains in a Neutron-Irradiated 304 Stainless Steel, J. Nucl. Mater. 452 (2014) 500-508. doi:10.1016/j.jnucmat.2014.05.053.

[21] M.N. Gussev, K.G. Field, J.T. Busby, Deformation localization and dislocation channel dynamics in neutron-irradiated austenitic stainless steels, J. Nucl. Mater. 460 (2015) 139-152. doi:10.1016/j.jnucmat.2015.02.008.

[22] K. Wang, Y. Dai, P. Spätig, Microstructure and fracture behavior of F82H steel under different irradiation and tensile test conditions, J. Nucl. Mater. 468 (2016) 246-254. doi:10.1016/j.jnucmat.2015.09.031.

[23] C.J. Boehlert, S.C. Longanbach, M. Nowell, S. Wright, The evolution of grain-boundary cracking evaluated through in situ tensile-creep testing of Udimet alloy 188, (n.d.). doi:10.1557/JMR.2008.0058.

[24] A. Clair, M. Foucault, O. Calonne, Y. Lacroute, L. Markey, M. Salazar, et al., Strain mapping near a triple junction in strained Ni-based alloy using EBSD and biaxial nanogauges, Acta Mater. 59 (2011) 3116-3123. doi:10.1016/j.actamat.2011.01.051. 